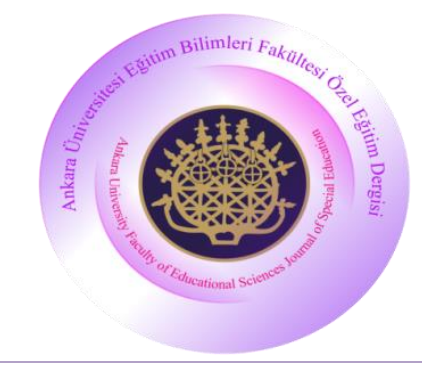

\section{Ankara Üniversitesi Eğitim Bilimleri Fakültesi Özel Eğitim Dergisi}

Yıl: 2018, Cilt: 19, Sayı: 2, Sayfa No: 303-334

DOI: 10.21565/ozelegitimdergisi.315887

\title{
Zayıf Okuyucuların Okuduğunu Anlama Becerilerinin Geliştirilmesinde Ana Fikir Belirleme Becerisinin Öğretimi
}

\author{
İlhan İlter \\ Kahramanmaraş Sütçü İmam Üniversitesi
}

Öz

\begin{abstract}
Bu çalışmada, okuduğunu anlama becerilerinin gelişimi için ana fikir belirleme becerisi ile ilgili verilen doğrudan öğretimin okuduğunu anlamada güçlük çeken üç dördüncü sınıf öğrencisi üzerindeki etkileri incelenmiştir. Araştırmada, yoklama evreli denekler arası çoklu yoklama deseni kullanılmış ve elde edilen veriler grafiksel analiz yoluyla analiz edilmiştir. Katılımcıların öğretim oturumlarında ve toplu yoklamalarda okuduğunu anlama performansı öyküleyici metinlerden oluşan kısa cevaplı sorular aracılığıyla değerlendirilmiştir. Ana fikir ve ayrıntı belirleme becerilerinin kalıcılığı ise öğretim uygulaması sonunda üçüncü ve beşinci haftalarda incelenmiştir. Ayrıca çalışmada, uygulanan programın etkilerinin niteliksel boyutlarını değerlendirmek amacıyla sosyal geçerlik verilerine yer verilmiştir. Araştırma bulguları, ana fikir belirleme becerisi üzerine yapılan öğretimin ana fikir ve ayrıntıları belirleme becerilerini öğrenme ve öğrenilen becerilerin kalıcılığını sürdürme konusunda her üç katılımcıya katkı sağladığını ve başlama düzeyi evresine kıyasla daha yüksek düzeyde bir okuduğunu anlama performansı elde edildiğini göstermiştir. Tüm sonuçlar, okuduğunu anlama becerilerinin geliştirilmesinde doğrudan öğretim modeli kullanılarak yapılan ana fikir belirleme becerisi öğretiminin katılımcı öğrenciler için etkili bir yöntem olduğunu göstermiştir.
\end{abstract}

Anahtar sözcükler: Okuduğunu anlama, ana fikir, ana fikir belirleme becerisi, doğrudan öğretim, iyi ve zayıf okuyucular.

\section{$\underline{\text { Önerilen Atıf Sekli }}$}

İlter, İ. (2018). Zayıf okuyucuların okuduğunu anlama becerilerinin geliştirilmesinde ana fikir belirleme becerisinin öğretimi. Ankara Üniversitesi Ĕ̆itim Bilimleri Fakültesi Özel Eğitim Dergisi, 19(2), 303-334. doi: 10.21565/ozelegitimdergisi.315887

\footnotetext{
*Sorumlu Yazar: Dr., E-posta: iilter@ksu.edu.tr, https://orcid.org/0000-0002-4411-200X
} 
Günümüz gençliğinin iş ortamının taleplerine ayak uydurabilmesi için önceki nesillerden daha gelişmiş okuryazarlık becerilerine sahip olması gerekmektedir (Biancarosa ve Snow, 2006). Bilim ve teknolojide yaşanan hızlı gelişmeler ve değişimler nedeniyle okulda ve toplumsal yaşamda etkin demokratik vatandaşlar yetiştirmek için okuduğunu anlama, problem çözme, eleştirel düşünme ve karar verme gibi becerilerin ve eğilimlerin geliştirilmesinin önemi her geçen gün artmaktadır. Bu nedenle öğrencilere okul sonrası yaşamlarında başarılı olmaları için zorlu ve karmaşı akademik görevlerle baş etmelerine yardımcı olacak yüksek düzeyli okuma ve düşünme becerilerinin kazandırılması önerilmektedir (Smagorinsky, 2001). Araştırmacılara göre okuma öğretiminin temel amacı, öğrencilerin okuduklarından anlam çıkarması ve bunları gündelik yaşamlarındaki iletişim görevlerinde ve gelecekteki akademik çalışmalarının çoğunluğunda kullanmalarına yardımcı olmaktır. Nitekim eğitim sisteminin temel amacı da okuyan, okuduğunu anlayan, bilginin gerçekliğini sorgulayan, duygu ve düşüncelerini açıklayabilen, kendi öğrenme yöntemlerini keşfetmiş ve öğrendiklerini toplumsal yaşama uygulayabilen etkili bireyler yetiştirmektir (Karatay, 2014; Stevens, Slavin ve Farnish, 1991).

Okuma ve okuduğunu anlama insana farklı bakış açıları kazandıran ve yaşamı yeniden anlamlandırmaya imkân veren becerilerdir (Kuşdemir ve Güneş, 2014). Okuduğunu anlama başarısı için ana fikir belirleme, yorumlama, çıkarımda bulunma ve özetleme becerileri büyük önem taşımaktadır. Bu tür beceriler okuma eğitimi üzerinde bilişsel boyut içerisinde yaygın olarak kabul edilen akademik hedefler arasındadır (Jitendra ve Gajria, 2011). Okuduğunu anlama becerisi, okuyucuya metinden önemli anlamlar çıkarma imkânı sunmak için okumayla birlikte kullanılması gereken karmaşık bilişsel süreçleri içermektedir. Okuduğunu anlamada akademik görevler arasında ana fikirler üzerinde yoğunlaşma, içsel tutarlılık, ön bilgi ve sağduyu ile içeriğin eleştirel olarak değerlendirilmesi, paragraftaki önemli fikirlerin sentezlenmesi ve anlamın oluşup oluşmadığını görmek için süregelen faaliyetleri periyodik gözden geçirme, kendini sorgulama ve izleme yer almaktadır (Brown, Palincsar ve Armbruster, 1984; Smagorinski, 2001; Taraban, Rynearson ve Kerr, 2000). Ancak okuma üzerine çalışmalar yürüten araştırmacılar okuduğunu anlama becerileri arasında en temel olanını ana fikir belirleme becerisi olarak açıklamıştır. Bu araştırmacılara göre okuyucuların yazılı materyalleri anlamlandırmalarına yardımcı olmak için ana fikir belirleme becerisi okuma ve okuduğunu anlama öğretiminin öncelikli amacı olmalıdır. Çünkü ana fikir belirleme ya da üretme okuduğunu anlamanın merkezinde yer alır (Aulls, 1986; van den Broek, Lynch, Naslund, Ievers-Landis ve Verduin, 2003; Tomitch, 2000). Metnin ana fikrinin bilinmesi metni özetlemek, metinde geçen olayları ve anahtar fikirleri açıklamak, genel metin yapısını tanımlamak ve metin içindeki bilgileri bütünleştirmek için okuyucuyu destekleyecektir. Ana fikrin belirlenmesi, okuyucunun çoğunlukla metinden önemli bilgileri ve fikirleri keşfetme kapasitesinin belirlenmesi için değerlendirilir (Kathleen, 2015).

Ana fikir kavramı, Türk Dil Kurumu Türkçe Sözlüğünde "Bir yazının temeli olan asıl düşünce" olarak tanımlanır (TDK, 2005, s. 94). Aktaş ve Gündüz (2001), ana fikri yazarın metinde ulaşmak istediği amacın en kısa ifadesi olarak tanımlamış ve ana fikir cümlesini "metinde anlatılanların bir yargı oluşturabilecek şekilde somut halde dile getirilmesi”" şeklinde ifade etmiştir. Diğer araştırmacılar ana fikri,"yazarın metindeki konuyla ilgili okuyucuya açık veya gizli olarak vermek isteği merkezi nokta ya da asıl mesaj" olarak tanımlamıştır (Duffelmeyer ve Duffelmeyer, 1991; Karataş, 2004). Bir metnin ana fikrini belirleme ise okuduğunu anlama için temel bir beceridir ve açımlama (metni başka sözcüklerle ifade etme), not alma, tahmin etme, bağlam ipuçlarını analiz etme, özet çıkarma gibi stratejiler için bir ön koşul olarak kabul edilir. Ana fikirler, okuduğunu anlama performansı için okuyucunun metinden uygun çıkarımlar yapması ve metinsel bilgiyi derinlemesine analiz edip değerlendirmesi ve yeni fikirler üretmesi açısından bir temel teşkil eder (Oxford, 1990; Williams, 1988). Bu bakımdan öğrencilere ana fikrin bulunma şeklinin öğretimi, bir metinde anlatılmak istenen en önemli bilgiyi ayırt etmesine ve okuduklarından kendilerince sonuç çıkarmasına yardımcı olmaktadır (Watson, Gable, Gear ve Hughes, 2012).

Pressley (2002), iyi bir okuyucunun özelliklerini tarif ederken açımlama ve özetleme becerilerinden bahsetmektedir. Pressley'e göre özetleme, okuyucunun açımlama becerisini kullanarak bir metni yeniden ifade etmesini gerektirir. Burada bahsedilen açımlama, okuyucunun metindeki her bir paragrafı okuyarak önce onu çeşitli yönleriyle tanımlayan ayrıntıları belirlemesi ve paragrafın konusuna karar vermesi, ardından bunları dikkate alarak metnin ana fikri hakkında sorular sorması ve orijinal cümleler halinde ana fikri ifade etmesidir (Katims ve 
Harris, 1997). Araştırmalar, açımlama becerisini kullanan öğrencilerin daha çok ana fikir ve anahtar kavramları hatırladıklarını göstermiştir (Hagaman ve Reid, 2008; İlter, 2017a; Lauterbach ve Bender, 1995). Bu noktada öğrencilere bir dizi belirli okuduğunu anlama stratejileri konusunda öğretim sunmak öğrencilerin sadece kavrama becerilerini artırmakla kalmayacak aynı zamanda bu araçların onların sahip oldukları okuma becerilerini nasıl geliştireceğine dair farkındalıklarını da artıracaktır (Beck, Buehl ve Barber, 2015). Nitekim öğrencilerin bilişsel stratejileri öğrenmelerini desteklemek için okuma öğretiminde stratejik öğretim modeli gereklidir (Reid, Lienemann ve Hagaman, 2013). Çünkü stratejik öğretim modeli öğrenciye nasıl öğreneceğini ve öğrendiği bilgi, fikir, içerik, beceri veya stratejileri özgün durumlara bağımsız bir şekilde nasıl uygulayacağını öğretmeye odaklanan bir yaklaşımdır. Temeli deneye dayanan bilişsel yöntem eğitiminin bir örneği olarak strateji öğretimi öğrencilere bilgiyi aktif ve düşünceli bir şekilde işlemeleri için belirli stratejiler öğretmeye odaklanmaktadır (Deshler ve Lenz, 1989). Okuma üzerine strateji öğretimi ise okullarda öğrencilerin anlama becerilerini geliştirmek ve hedeflenen bilgiyi işlemesine yardım etmek için etkili uygulamalardan biridir (Hagaman ve Reid, 2008). Buna göre okuma stratejileri konusunda öğrencilere iyi bir öğretim sağlamak (yüksek kalitede öğrenmeyi destekleme) özellikle okuduğunu anlamada problem yaşayan öğrencilerin metinleri anlamada yaşadıkları zorlukların üstesinden gelmelerine yardımcı olabilir (Pressley ve McCormick, 1995).

Araştırmacılar, okuduğunu anlama konusunda strateji öğretimine daha fazla önem verilmesi gerektiğini vurgulamıştır (Akyol, 2011; Alfassi, 2004; İlter, 2017a). Snyder ve Pressley (1995), öğretmenlerin bilişsel yöntem eğitimini kabul etmeleri ve derslerinde strateji öğretimine yeterli zamanı ayırmaları gerektiğini açıklamıştır. Genel eğitim sınıflarında anlama güçlüklerinin giderilmesinde bu kriterleri karşılayan bir uygulama da ana fikir belirleme becerisi öğretimidir (Jitendra ve Gajria, 2011). Çünkü ana fikri belirleme becerisi öğretimi öğrencilerin diğer kritik becerileri kazanmalarını destekleyecek bir yetenektir(Kathleen, 2015). Ana fikir belirleme becerisinin öğretimindeki amaç okuyucunun yazılı materyalde anlatılmak istenen temel düşüncelerin önem düzeylerini belirleyebilmesi için gerekli becerileri kazanmasına yardımcı olması ve daha ileri bir akademik hedefi başarabilmesidir (Aulls, 1986). Dolayısıyla ana fikir belirleme becerisi metni kavrayabilmek ve metinden elde edilen kazanımları en üst düzeye çıkarabilmek için okuma-yazma eğitiminde gerekli bir basamaktır. Bu kritik önkoşul becerisi, öğrencilerin metni özetleme, fikirleri metinler arasında bütünleştirme ve metnin genel yapısını tespit etme kapasitesini desteklemektedir. Bir başka deyişle, öğrencilere ana fikri öğretmek uzun vadede faydalı olacak değerli bir yatırımdır (Kathleen, 2015; Rand Reading Study Group, 2002).

\section{Zayıf Okuyucuların Okuma Becerilerine İlişkin Özellikleri}

Başarılı bir okuyucu olmak için bireyin okuma sürecinde aktif olması önemlidir. Öğrencinin okuduğu bir metnin ana fikrini belirleyebilmesi için kendiliğinden bazı stratejileri uygulaması gerekir (Carnine, Silbert ve Kame'enui, 1997). Ancak etkili okuma stratejilerine sahip olmayan öğrenciler okuduklarından anlam çıkaramazlar ve bu nedenle okuma motivasyonu önemli ölçüde azalır (Guthrie, 2008; Pitcher ve diğ., 2007). Başarılı veya iyi okuyucular stratejiktir sadece okumazlar, aynı zamandametin okuma sirasında kendi anlama sürecini izleme yoluyla anlamalarını sorgulayarak karşılaştığı problemlerin farkına varabilirler (Akyol, 2011). Bu okuyucular metinle etkileşim kurarak kendine sorular sorar, tahminlerde bulunur, fikirleri düzenler, ana fikri destekleyen ayrıntıları belirler, özetler oluşturur ve anlama ve strateji kullanımını sürekli olarak izlerler (Kiewra ve DuBois, 1998). Akyol (2010), iyi okuyucuların amaçlı okuduklarını, okumadan önce metni gözden geçirdiklerini ve metnin yapısına dair bir farkındalık geliştirdiklerini açıklamıştır. Ancak daha az yetenekli öğrenciler veya zayıf okuyucular, okuduğunu anlamada ciddi sorunlar yaşamaktadır. Zayıf okuyucular, metinlerdeki ana fikirleri içeren semantik bağlam ipuçlarını daha az algılayabildiğinden bilinmeyen kelimelerin ilgili anlamını bağlamdan otomatik olarak çıkaramamakta ve ana fikir belirleme görevine aracılık eden üstbilişsel stratejileri (örn., metnin anlamına dayalı bir tahmin yürütme) kullanmada yetersiz olmaktadırlar (İlter, 2017b; Stanovich, 1986).

Zayıf okuyucular, ana fikirle bağlantılı bilgileri ve alt-üst fikir örneklerini düzenleme, bir süreç içerisindeki devamlı ve birbirine bağlı olayların akışını sıralama, kategorize etme becerilerinden yoksundur. Bundan dolayı içeriğin tamamının ne hakkında olduğu ile ilgili bir fikre ulaşmada ya da metnin büyük resmini ortaya çıkarmada daha kesin ve hızlı bir ilerleme kaydedemezler. Bu tür okuyucular başarılı okuyuculara kıyasla 
metinde anlatılmak istenen ana düşünceleri ve metnin konusuna ilişkin anahtar kavramları daha az hatırlama eğilimindedirler (Spring ve Prager, 1992; Torgeson, 1982; Warren ve Fitzgerald, 1997). Kuhn ve Stalh (1998), zayıf okuyucuların okuma uygulamalarına olumsuz bir tutumla yaklaştığını, kendi okuma davranışlarını açıkça analiz edemediğini ve sınırlı kelime dağarcığı nedeniyle metnin paragraflarını ya da metnin tamamını anlamada belirgin problemler yaşadıklarını açıklamıştır. $\mathrm{Bu}$ okuyucular, daha az kelime dağarcığıyla okumaya başladıklarından okuduğunu anlamada olumsuz bir döngüye kapılırlar. Okuyucu gitgide hayal kırıklığına uğradığ için bu süreçte gerginlik ve endişe duygusu yaşayabilir, farklı vücut hareketleri ve anlık duygusal tepkiler sergileyebilirler (Halladay, 2012). Motivasyon eksikliği ise okuyucunun kelime dağarcığı ve anlama becerilerini desteklemesinde ve güçlü okuma stratejileri geliştirmesinde olumsuz etkiler bırakmaktadır (Roberts, Torgesen, Boardman ve Scammacca, 2008). Araştırmacılar, bu tür okuma deneyimlerinin okuyucuda kötü okuma alışkanlıkları doğurabileceğini ve daha fazla stres ve hayal kırıklığına neden olacağını savunmuştur (Mariotti ve Homan, 2001; Tompkins, 2006). Winograd ve Jonhson (1982), zayıf okuyucuların başarısızlıklarını çoğunlukla okuyucunun ön bilgi eksikliğine ve yetersiz anlama stratejisi kullanımına bağlamıştır.

\section{Ana Fikir Belirleme İçin Strateji Öğretimi}

Bir metnin ana fikrini çıkarmak basit bir iş değildir ve çoğunlukla da ana fikirler metinde açık bir şekilde ifade edilmezler(Chang ve Ku, 2014; Hennings, 1991). Bir yazının ana fikrini belirlemek için okuyucunun kendisine sorular sorması gerekir. Bu sorular "Metindeki ögeleri bütün metinle birleştiren fikir nedir?, Tüm parçalar hangi fikri destekliyor?, Metnin çoğunluğunda hangi fikirler ortaktır?, Hepsinin açıklaması veya tarif ettiği fikir nedir?, Ana fikri hangi cümle belirtir?"şeklindedir. (Clarke, 1996; Akt. Tomitch, 2000). Okuyucudan ön bilgisini kullanarak metinle etkileşim kurması, metindeki unsurlar arasında ilişkilendirmeler yaparak sorular sorması, açık olarak ifade edilen ayrıntılardan öteye giderek anlam çıkarması beklenmektedir. Okuyucu, her paragrafin konusunu belirlemeli, benzer fikirleri sentezlemeli, gereksiz ve alakasız fikirleri göz ardı ederek, açık bir ana fikir ifadesi oluşturmalıdır (Karatay, 2014; Kintsch ve van Dijk, 1978).

Araştırmacılar okuduğunu anlama üzerine yürüttükleri çalışmalarda pek çok öğrencinin okuduğunu anlama, ancak daha çok ana fikir belirleme konusunda zorluk çektiğini saptamıştır (Kathleen, 2015). Kiewra (1987) çalışmasında, öğrencilerin not alırken karşılaştığı en büyük problemin ana fikirleri belirlemek olduğunu ve metinde en önemli bilgileri ön plana çıkarmakta başarısız olduğunu tespit etmiştir. Bu çalışmada, öğrencilerin ana fikri metnin yüzeyinde (tekrar eden kelimeler, alt başlıklar, sıralı örnekler vb.) aramaya çalıştıkları, metnin konusuyla ana fikrini karıştırdıkları ve metne ilişkin çıkardıkları notlarda kelimesi kelimesine kopyalama yöntemini kullandıkları görülmüştür. Yakın zamanda Çetinkaya, Ateş ve Yıldırım (2013) tarafından yapılan bir araştırmada, öğrenme güçlüğü olmayan ortaokul beşinci sınıf öğrencilerinin ana fikir ve metnin konusu arasında ayrım yapamadığı, ana fikrin belirlenmesinde yaşanan güçlükler nedeniyle metinlerin anlaşılmadığı belirlenmiştir. Araştırmacıların bir kısmı okuduğunu anlamayla ilgili problemlerin okuma üzerine strateji öğretimi eksikliğinden kaynaklandığını belirtirken (Cox, 1997; Fordham, Wellman ve Sandmann, 2002; Garner, 1990; Kathleen, 2015); bir kısmı da öğrencilerin sınırlı kelime dağarcığı ve okuduğunu anlamaya temel oluşturan üstbilişsel strateji bilgisinden kaynaklandığını düşünmektedir (Vacca ve Vacca, 2007; Williams, 1986, 2004).

Atkinson ve Shiffrin'in (1968) bilgi işlem teorisine göre öğrenciler okuma ve not alma sürecinde bilişsel aşırı yükleme ve baskıyla karşılaşıllar. Kısa süreli belleğe yapılan aşırı yüklemeler metindeki bazı bilgilerin, anahtar kavram ya da ana fikirlerin kısa süreli bellekte kaybolmasına veya yer değiştirmesine yol açmaktadır (Just ve Carpenter, 1992; Rafoth, Leal ve Defabo, 1993). Bu hipoteze göre çalışma belleğindeki baskıyı ve bilişsel yükü azaltmak için öğrencilere etkili stratejilerin kazandırılması gerekmektedir. Çünkü öğrenme stratejileri öğretimi, yazılı veya sözel materyali anlamak için çalışma belleğindeki baskıyı veya yükü hafifletir, gereksiz bilgiyi ayırt ederek ilgili bilgiyi işlemeye, fikirleri sentezlemeye ve uzun süreli belleğe kodlamaya yardımcı olur (Gathercole, Durling, Evans, Jeffcock ve Stone, 2007; Just ve Carpenter, 1992; Peverly ve Sumowski, 2012). Buna göre öğrenciler okuma yeterliliği için etkili öğrenme stratejilerini elde etmeleri konusunda teşvik edilmelidir (Samuelstuen ve Braten, 2005). Çünkü okuma ve okuduğunu anlama büyük oranda zihinsel bir süreçtir. Bu süreçte okuyucunun metindeki her cümlenin, her paragrafın veya bölümün merkez noktasını analiz ederek yazarın istediği 
mesajı ustaca irdeleyip ana fikri belirlemesi gerekmektedir (Kathleen, 2015). Nitekim metinden anlam çıkarabilme yeteneği okullarımızdaki genel başarı için en önemli becerilerden biridir (Güneş, 2000; Williams, 1988). Bu bakımdan öğrencilere etkili bir strateji olarak ana fikrin nasıl bulunacağını öğretmek okuduğunu anlama yeterliliği için oldukça önemlidir. Bununla birlikte ana fikir belirleme stratejisi öğretimiyle ilgili yapılan çalışmalar, bu stratejinin öğrencilerin okuduğunu anlamaları üzerinde önemli katkılar sağladığını göstermiştir (Jitendra, Hoppes ve Xin, 2000; Klingner, Vaughn ve Schumm, 1998; Malone ve Mastropieri, 1992; Stevens ve diğ., 1991; Williams, Brown, Silverstein ve deCani, 1994).

$\mathrm{Bu}$ çalışmanın amacı, doğrudan öğretim yoluyla ana fikir belirleme becerisi öğretiminin okuduğunu anlamada problem yaşayan dördüncü sınıf öğrencilerinin okuduğunu anlama performansı üzerindeki etkilerini değerlendirmektir. Ana fikir belirleme, okuduğunu anlamada eleştirel ve merkezi bir beceri olduğu için bu çalışma için okuduğunu anlama becerileri öğretiminde odak nokta olarak belirlenmiştir (National Reading Panel, [NRP], 2000). Ayrıca bu çalışma, ana fikir belirleme becerisi öğretiminin öğrencilerin okuduğunu anlama performansını geliştirip geliştirmediğini incelemek ve öğrenilen becerilerin devam edip etmediğini gözlemlemek amaciyla yürütülmüş̧ür. Alanyazın incelendiğinde, ülkemizde ana fikir ve ana fikri destekleyen ayrıntıları belirleme becerileri öğretimi ile ilgili deneysel çalışmaların sınırlı düzeyde olduğu görülmüştür (Kuşdemir ve Güneş, 2014; Pilten, 2007). Buna göre bu çalışmanın başta okuduğunu anlamada problem yaşayan öğrencilerin okuduğunu anlama becerilerini geliştirmek isteyen öğretmenlere, daha sonra ilgili alanyazına ve gelecek araştırmalara önemli katkılar sağlayacağı düşünülmektedir. Bu amaç kapsamında aşağıdaki araştırma sorularına yanıt aranmıştır:

1. Ana fikir belirleme becerisi öğretimi zayıf okuyuculara okuduğunu anlama becerilerinin kazandırılmasında ve bu becerilerin öğretim sona erdikten belli bir süre sonra da korunup kalıcılığının sağlanmasında etkili midir?

2. Araştırmaya katılan öğrencilerin ana fikir belirleme becerisi ile ilgili uygulanan öğretim programı hakkındaki görüşleri nelerdir?

\section{Yöntem}

\section{Katılımcılar ve Ortam}

Araştırmaya Bayburt ilinde yer alan ve orta-sosyoekonomik olarak düşünülen bir ilkokulun dördüncü sınıflarından rastgele seçilen bir şubede öğrenim gören 11'i erkek ve 7'si kız olmak üzere 18 öğrenci arasından bir okuduğunu anlama değerlendirme aracıyla üst üste yapılan iki değerlendirmede \%50'inin altında puan alan üç öğrenci katılmıştır (İkinci değerlendirme iki hafta sonra yapıldı). Bu öğrencilerin okuduğunu anlama ölçümlerinde iki kez ortalama puanlarının altında bir puan aldığı belirlenmiştir. Yapılan değerlendirmelerde öğrencilerin değerlendirme aracındaki sorulara verdiği doğru cevaplarının yüzde olarak ortalaması 28.97 bulunmuştur (en düşük \%24.5 ve en yüksek \%36.78). Bu sınıflarda öğrenim gören ve yapılan iki değerlendirmede \%50 ve üzerinde puan alan öğrenciler çalışmanın kapsamı dışında tutulmuştur. Çünkü ana fikir belirleme becerisi öğretiminin yalnızca okuduğunu anlamada güçlük çeken öğrencilere yapılması amaçlanmıştır.

Ana fikir belirleme becerisi öğretimi öncesi araştırmacı (çalışmanın yazarı) öğrencilerle ilgili bazı demografik bilgiler elde etmek için öğrencilerin öğretmeni ile görüşmeler gerçekleştirmiştir. Öğretmene bu öğrencilerin isimleri ve değerlendirme aracından aldı̆̆ı puanlarının bir nüshası verilmiştir. Katılımcıların ismi etik kurallar gereği gizlenmiş ve bunların yerine kod isimleri kullanılmıştır. Buna göre birinci katılımcıya kod adı olarak Kadir, ikincisine Ayşe ve üçüncüsüne de Erkan adı verilmiştir. Kadir 10 yaşında bir öğrencidir. Kadir'in üst üste yapılan iki yapılan değerlendirmede doğru cevaplarının yüzde olarak ortalaması 28.25 olarak bulunmuştur. Sınıf öğretmeni ile yapılan görüşmelerde, Kadir'in metinlerde ana fikirleri belirleme ve metinden uygun çıkarımlar yapmada güçlük yaşadığı görülmüştür. İkinci katılımcı Ayşe ise dokuz yaşındadır ve değerlendirme aracında sorulara verdiği doğru cevapların yüzde ortalaması 33.64'tür. Öğretmen Ayşe'nin sınıfta okurken kuruntulu ve sinirli olduğunu, okumaya karşı olumsuz bir tutum sergilediğini ve bu durumun okuma ve okuduğunu anlamada güçlükler yaşamasına neden olduğunu paylaşmıştır. Üçüncü katılımcı Erkan ise 10 yaşındadır ve ortalaması \%25.02'dir. Öğretmen değerlendirmesine göre, Erkan sınırlı düzeyde kelime dağarcığına ve okuduğunu 
anlama/anlam oluşturma becerilerine sahiptir. Bu durum Erkan'ın metinleri kavramasını ve metinle ilgili yeni fikirler üretmesini güçleştirmektedir. Öğretmen, Erkan'ın sınıfta dinleme ve okuma esnasında okuduğunu anlama ile ilgili sorulan sorulara doğru cevap veremediğini ve özet çıkarırken uzun uzun yazılar yazdığını açıklamıştır. Öğretmen görüşleri ve okuduğunu anlama değerlendirme aracından elde edilen tüm veriler bir bütün olarak ele alındığında, bu öğrencilerin okuduğunu anlamada yetersiz olduğu anlaşılmaktadır. Nitekim öğretmen geçmiş zamanlarda yaptığı sınavlarda bu öğrencilerin düşük notlarını belgelendirerek bunları doğrulamıştır.

$\mathrm{Bu}$ adımdan sonra araştırmacı katılımcı öğrencilerin ebeveynlerinden onay almak için okul yönetimi rehberliğinde ebeveynlerle uygun gün ve zamanda okulda yüz yüze görüşmeler gerçekleştirmiştir. Görüşme sırasında araştırmacı öncelikle kendi uzmanlık alanından ve çalışmalarından bahsetmiş daha sonra öğretim programının içeriğine ve amaçlarına kısaca değinmiştir. Görüşme neticesinde katılımcıların ebeveynlerinden yazılı onay alınarak öğretim uygulamasına başlanmıştır. Katılımcılara ilişkin demografik özellikler ve başlangıç okuduğunu anlama puanları Tablo 1'de gösterilmiştir.

Tablo 1

Katılımcıların Demografik Özellikleri ve Başlangıç Okuduğunu Anlama Düzeyleri

\begin{tabular}{lccccc}
\hline \multirow{2}{*}{ Öğrenci } & \multirow{2}{*}{ Cinsiyet } & \multicolumn{3}{c}{ Okuduğunu Anlama Değerlendirme Aracı } & \multirow{2}{*}{ Yaş } \\
\cline { 3 - 4 } & & \multicolumn{2}{c}{ Sorulara Verilen Doğru Cevapların Yüzdesi } & \multirow{2}{*}{10} \\
\cline { 3 - 5 } Kadir & Erkek & I. Değerlendirme & II. Değerlendirme & Ort. & \\
Ayşe & K1z & $\% 27.5$ & $\% 29.5$ & $\% 28.25$ & 9 \\
Erkan & Erkek & $\% 30.5$ & $\% 36.78$ & $\% 33.64$ & 10 \\
\hline
\end{tabular}

Deneysel uygulama araştırmacı tarafından yürütülmüştür. Araştırmacı, yükseköğretimde on iki yıllık bir deneyime sahip olup okuma uygulamaları ve çalışma becerileri konusunda çeşitli bilimsel çalışmalar yürütmüştür. Ana fikir belirleme becerisi ile ilgili verilen öğretim oturumları, araştırmanın yürütüldüğü okulda uygun bir derslikte geçekleştirilmiştir. Bu derslik $30 \mathrm{~m}^{2}$ 'lik bir alana sahiptir ve içerisinde birer adet sınıf tahtası, projeksiyon cihazı, bilgisayar, perde, öğretmen masası, pano ve beş adet öğrenci sırası yer almaktadır.

\section{Bağımlı Değişken}

$\mathrm{Bu}$ çalışmanın bağımlı değişkeni okuduğunu anlamada güçlük çeken öğrencilerin okuduğunu anlama becerilerindeki gelişim düzeyleridir. Okuduğunu anlama başarı düzeyi, öğrencilerin bağımsız olarak öyküleyici metinlerde ana fikir cümlelerini belirleme ya da üretme, paragraflardaki ayrıntıları tanımlama, metindeki bilgileri kavrama ve organize etme ve metinden uygun çıkarımlar geliştirme yeteneği olarak tanımlanmıştır.

\section{Bağımsız Değişken}

Çalışmanın bağımsız değişkeni "Stratejik Öğretim Modeli’nin” (Ellis, Deshler, Lenz, Schumaker ve Clark, 1991) değiştirilmiş bir versiyonu ile bağdaştırılan "Doğrudan Öğretim Modeline"dayalı yürütülen ana fikir belirleme becerisi öğretimidir. Williams (1988), ana fikirleri belirleme becerisi için doğrudan öğretim şeklini etkili bir araç olarak tanımlamıştır. Doğrudan öğretim öğretmenin öğrenme ve öğretme sürecini açık bir şekilde yönettiği, temelinde demonstrasyon ve modellemenin yapıldığı; rehberli ve bağımsız uygulamaların ve dinamik değerlendirmelerin gerçekleştiği bir öğretim şeklidir. Doğrudan öğretim genel olarak öğrencilere okuduğunu anlama becerileri ve düşünme stratejilerini öğretmede kullanılır. Doğrudan öğretim, öğrenciler yeni becerileri öğrendikçe onlara rehberlik edilen bir öğretim hizmeti sunar. Bu öğretim modeli içinde, öğretmen kavrama süreçlerinin nasıl sesli düşünüleceğini yaptığı adım adım rehberlik, açık modelleme, doğrudan yönergeler ve düzeltici geri bildirimler yoluyla öğrencilerin öğrenmeye katılımları için çaba harcar (Burke, 2012; Roehler ve Cantlon, 1997). Araştırmada doğrudan öğretim şekli ise ana fikir belirleme derslerinin amacının belirlenmesi, öğrencilere ana fikir belirleme görevin öneminin ve işlevinin açıklanması, yeni öğrenilenlerin önceki öğrenilenlerle birleştirilmesi konularını içermektedir. Doğrudan öğretim ayrıca ana fikir belirleme yöntemi kuralları ile ilgili açıklamaları sunma, yöntemi modelleme, öğrencinin kavrama durumunu kontrol etme, yöntemin 
kazanımı, hataları düzeltmeye yardımcı olan geribildirimler sunma ve hem rehber eşliğinde hem de bağımsız yapılan uygulamalara ilişkin yeterli firsatların sunulması konularını içermektedir (Jitendra, Cole, Hoppes ve Wilson, 1998).

\section{Öğretim Programı}

Ana fikir belirleme öğretim programı Carnine ve diğerlerinin (1997) önerdiği öğretim programından uyarlanmış ve Jitendra ve Gajria (2011) ve Jitendra ve diğerleri (1998) tarafindan geliştirilen bir dizi yedi dersten oluşmaktadır. Her bir ders"Doğrudan Öğretim Modeli” kullanılarak öğrencilere uygulanmıştır. Öğretim uygulamaları yaklaşık on sekiz gün sürmüştür. Öğrenciler her ders için ana fikir belirleme konusunda yeterli düzeye ulaşıncaya kadar öğretim oturumlarına düzenli olarak devam etmiştir. Her derste yapılan öğretim haftada bir ile üç gün (toplam 15 oturum) arasında değişmiştir. Dersler için planlanan her bir oturum süresi genel olarak 20-30dakika arasındadır. Ancak bu süre katılımcının performansına veya ihtiyacına göre değişiklik gösterebilmektedir. Öğrencilerin okulda diğer derslerden geri kalmamasına özen gösterilmiştir.

Uygulamacı öğretim uygulaması boyunca öğretmenle sürekli iletişime geçmiş ve haftalık rutin değerlendirme toplantıları gerçekleştirmiştir. Ana fikir belirleme becerisi öğretim programındaki her bir ders bir önceki aşamada öğrenilen bilgi ve becerilerle genişletilmiştir. Dersler kolaydan zora doğru verilen görevlere karşı öğrencilerin okuma sürecinde özümseyebileceği ve kendiliğinden kullanabileceği çeşitli anlam kurma becerilerini (ör., ana fikir ve ayrıntı belirleme, açımlama, sonuç çıkarma) geliştirmek üzere sıralanmıştır. Öğretim etkinlikleri uygulamacının açıklamaları, ana fikir bulma kurallarıyla ilgili ifadeleri sunma, öyküleyici metin parçaları, ana fikir belirleme hatalarını düzeltmeye yardımcı olan geribildirimler, ana fikir belirleme alıştırmaları ve Jitendra ve diğerlerinden (1998) uyarlanarak geliştirilen ana fikir belirleme kartından (bkz. Şekil 1) oluşmaktadır.

Aşağıda verilen katılımcılara her bir dersle ilgili öyküleyici metinlerde ana fikir belirlemeyi öğretmek için verilen yedi dersin kısa bir özeti sunulmuştur (Carnine ve diğ., 1997; Jitendra ve Gajria, 2011).

Ders 1. Ana fikir kavramının tanımlanması. Bu dersin odaklandığı nokta öğrencilere ana fikir kavramının kısaca tanımlanmasıdır. Öğrencilere okuduğunu anlamanın öneminden, bu yeteneğin okul başarısına ve yaşama katkısından ayrıca ana fikir belirlemenin işlevinden bahsedilir. Okuduğunu anlamada problem yaşayan bireylerin toplum hayatında ne tür sorunlarla karşılaşacağına dair bilgi ve örnekler verilir. Bu öğretimin sonunda katılımcılara okuduğunu anlamada daha başarılı olacağ ve metinlerdeki ana fikirleri daha kolay belirleyebileceği yönünde cesaretlendirici övgülere yer verilir. Bu adımdan sonra ikinci derse geçilir.

Ders 2. Tek konulu ana fikir belirleme çalıșması. Bu derste uygulamacı, Șekil 1'te gösterilen ana fikir belirleme kartının bir kopyasını katılımcıya sunar ve nasıl kullanıldı̆̆ını öyküleyici bir kısa metin üzerinde sözlü bir şekilde model olarak onun zihninde canlı bir resim çizmeye çalışır. Uygulamacı bunun için metni sesli okur ve okurken renkli kalemler kullanarak metnin merkezinde yer alan kişiyi ve ana eylemi not eder ve bunlarla ilgili ayrıntıların altını çizer ve daha sonra bu kişinin davranışlarını ve gerçekleşen olayları kategorize eder. Somutlaştırmak için uygulamacı metindeki unsurlara bir grup adı verir ve ana eylemi sınıflandıran bir fiil söyler (Carnine, Silbert, Kame'enui ve Tarver, 2010). Uygulamacı okurken şu soruları sorabilir: "Metinde gerçekleşen olay neden söz ediyor?, Anlatılmak istenen en önemli fikir nedir?" Uygulamacı, bu soruların cevabını ana fikir kartına yazar ve katılımcıya gösterir. Uygulamacı katılımcıya bilişsel açıdan model olmak için "sesli düşünme" yöntemini kullanır. Daha sonra uygulamacı katılımcıya yeni bir metin parçasını verir ve bu metindeki paragrafları okuyarak hikâyedeki kişinin adını yazmasını, kişinin yapmış olduğu en önemli şeyi açıklayarak ana fikri kendi kavramlarıyla açıklamasını ister. Bu süreçte katılımcıdan ana fikirle bağlantılı ayrıntılar ve önemli kavramları incelemesi istenir. Uygulamacı ortaya çıkan hatalar durumunda düzeltici geribildirimler verir. Katılımcının ana fikir belirlemede başarılı bir performans gösterip göstermediğini belirlemek için uygulamacı katılımcıya yeni bir kısa metin parçası verir. Bunun için katılımcıya yeterli süre tanınır. Katılımcı metnin ana fikir belirlediğinde üçüncü derse geçiş yapılır. 
Metin. Doktor Namık Bey, Ege'deki tatil kasabalarından birinde, tatilini geçiriyor. Orada bakımlı, güzel bir bahçeyle çevrili, küçük bir evi var. Bir sabah erkenden yürüyüşe gitmek üzere evden çıkıyor. Ne var ki bahçe kapısının önünde yere boylu boyunca yatmış, yaralı bir leylekle yüz yüze geliyor. Leyleğin bacağı kırık. Koptu kopacak. Doktor durumu görünce yürüyüşten vazgeçiyor. Leyleği eve alıyor. Bacağını sarıyor. Bahçede ona bir yer yapıyor (Gülten Dayığlu) (Kısaltılmıştır.)

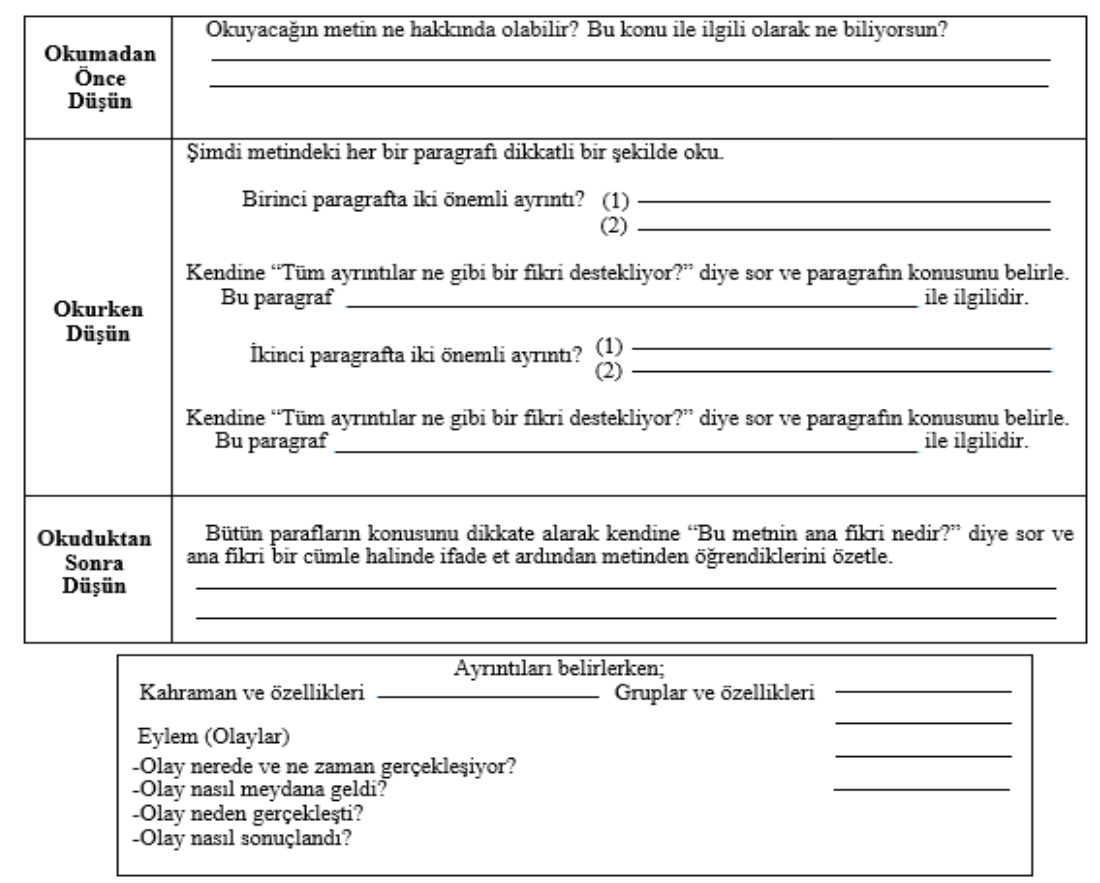

Şekil 1. Ana fikir belirleme kartı örneği.

Ders 3. Çok konulu ana fikir belirleme çalışması. Bu adımda verilen öğretim bir önceki dersteki gibidir. Ancak bu ders katılımcıya çok konulu bir metin verilerek bu metindeki kişileri adlandırmayı ve bir dizi eylemi sınıflandırmayı içermektedir. Ana fikir oluşturma kuralı, grubun adlandırılmasını ve bu grubun yaptığı temel eylemin sınıflandırılmasını, problemin tarif edilmesini ve hikâyenin gerçekte ne olduğunu belirlemeyi kapsamaktadır. Uygulamacı çok konulu metinde her bir paragraftaki ana eylemi ve farklı kişileri belirlemeye, bunların yaptıkları eylemleri kategorize etmeye ve en sonunda metnin ana fikir cümlesini yazmaya çalışır. Uygulamacı okumanın sonunda ana fikir cümlelerini belirlemek için "Metnin çoğunluğunda hangi fikirler ortaktır?, Bu fikirlerin açıkladığı ya da anlatmak istediği ana düşünce nedir?” sorularına yer verir. Uygulamacı, katılımcıya çok konulu yeni bir metin ve ana fikir belirleme kartını verir, katılımcıdan okuduğu metnin paragraflarında geçen kişileri belirleyip bir grup adı türetmesini ve gerçekleşen ana eylemi saptayarak kendi cümleleriyle ana fikir kartına ana fikir cümlesini yazmasını ister. Uygulamacı metinden çıkarılan ana fikrin doğru bir şekilde belirlenip belirlenmediğini kontrol eder. Katılımcı burada da başarılı bir performans gösterdiğinde dördüncü derse geçiş yapılır.

Metin. Etrafı beyaz çitlerle çevrili, büyük bir çiftlik vardı. Atlar, kuzular, keçiler, inekler, ördek ve tavuklar... Herkes birbirine yardım eder, elbirliğiyle tüm zorlukları yenerlerdi [...] Bu çiftlikte her şey iyiydi, hoştu ama düzeni bozan birisi vardı. O da, tembel tavuktu. [...]. Neredeyse yerinden bile kımıldamazdı. Sadece tembellikle kalmaz, birilerine yardım etmekten de nefret ederdi. Mesela geçen gün, bayan ördek yumurtasının 
üzerine yatarken nasıl olduysa yumurtanın biri yuvarlanıp tıngır mıngır tembel tavuğun kümesinin yanına kadar gelmişti. Yumurtaları sıcak kalması gereken ördek hanım telaşlandı...

-Tavuk kardeş, yardımcı olur musun bana? Yumurtam tam senin yanında, onu alıp bana getirir misin? diye sordu. Tavuk oralı bile olmamıştı.

-Aman niye yardım edecekmişim ki? Yorgunum ben, biraz dinlenmem lazım, diye cevap verdi ve uyumak için kümese tünedi. Zavallı bayan ördek diğer yumurtalarını bırakıp yuvarlanan yumurtasını kendisi almak zorunda kalmıştı. Neredeyse diğer yumurtalar soğuyacaktı (Damla Yayınevi). (Kısaltılmıştır.)

Ders 4. Çoktan seçmeli ögelerin tespiti yoluyla ana fikrin belirlenmesi. Bu ders, çoktan seçmeli ögelerin olduğu öyküleyici metinlerde çıkarılan ana fikir belirleme etkinliklerini içerir. Katılımcıya bir metni en iyi açıklayan ana fikir cümlesini seçmeden önce metinde tüm seçenekleri eleştirel olarak değerlendirmesi öğretilir. Uygulamacı bunun için çoktan seçmeli unsurları içeren yeni bir metin belirler ve sesli düşünme yöntemini kullanarak ve modelleme yaparak metinde tüm ölçülebilir unsurlar, kişiler ve olayları belirler ve bunları eleştirel olarak değerlendirir. Uygulamacı okuma sırasında "Şu ana kadar okuduklarım... ile ilgili olduğu görünüyor. Gerçekten metnin tam olarak neyle ilgili olduğunu öğrenmek için okumaya devam edip daha fazla kanıt (ana eylem, yer, zaman problem, çözüm vb.) elde etmeye çalışacağım.” şeklinde üstbilişsel ifadeleri açık bir şekilde dile getirir (Katims ve Harris, 1997). Bunu yaparken yine sesli düşünme yöntemini kullanır. Okuma sonunda uygulamacı katılımcıya bilişsel olarak model olmak için şu soruyu sorar: "Yazar, metinde hangi kişi ve olaylara yer vermiştir, “...” adlı olayın açıkladığı fikir nedir, ... paragrafta geçekleşen olayın sonuçları nelerdir, Tüm olaylar hangi düşünceyi destekliyor?” Uygulamacı katılımcıyla birlikte bu soruların cevabını tartışır ve metnin konusunu ve ana fikrini belirler. Ders 2 ve Ders 3'te olduğu gibi katılımcıya yeni bir metin ve ana fikir belirleme kartı verilerek kendisinden metnin ana fikrini ve ayrıntılarını belirlemede bağımsız alıştırmalar yapması istenir. Katılımcı başarılı denemeler gerçekleştirdiği an uygulamacı beşinci derse geçiş yapar.

Metin. Eski zamanlardan birinde zengin ve güçlü bir kral yaşarmış. Kralın iki tane ikiz oğlu varmış. Oğulları kralın tek mutluluk kaynağıymış. Bu çocuklar büyümüş koca adam olmuşlar. Fakat kralın bu mutluluğu pek uzun sürmemiş. Çünkü ikizlerin iştahı kesilmiş, gün geçtikçe sararıp solmuşlar, zayıflamışlar. Kral ülkedeki bütün doktorları, büyücüleri ve sihirbazları çağırmış, ama hiçbiri oğullarının bu sorununu çözememiş [...] (Anonim)(Kısaltılmıştır.)

- Kralın mutluluk kaynağı nedir?

- Kralın mutluluğu neden uzun sürmemiş?

- Kralın ikizlerine ne olmuş?

- Sizce bu paragrafin ana fikri ne olabilir?

Ders 5. Çeldirici cümlelerin ve gereksiz bilgilerin tespiti. Bu ders, bir metinde ana fikirle ilgili bilgi sağlamayan kelimeler veya cümleler dışında tüm diğer cümlelerin ana fikri desteklemesi gerektiğini vurgular. Dersin odaklandığı nokta, metindeki paragraflarda önemli bilgi parçalarını seçmek ve onu yoğunlaştırmaktır ki bu, bir metni özetlemeye benzer (Brown ve Day, 1983). Bu nedenle bu adımda katılımcıdan bir metin içerisinde paragrafların konusu ile ilgili kavramlar, anahtar fikirler ve önemli bilgi parçalarına yoğunlaşması beklenir. Bunun için uygulamacı katılımcıya bir metnin ana fikrini belirlemeden önce metindeki her bir paragrafta geçen çeldiricilerin (önemsiz şeyler, gereksiz bilgiler veya örnekler) altını çizerek belirlemeyi ve yazıdaki fazlalıkları silmeyi öğretir. Uygulamacı, katılımcıya bir paragraftaki bir örneği atlayarak ya da açıklayıcı tanımları çıkararak fazla bilgiyi nasıl elde edeceğini ve daha yüksek düzeyli fikirler (karşılaştırma, nedensellik, önermeler gibi iki veya daha fazla fikir arasındaki sözbilimsel ilişkiyi ortaya çıkan anahtar kelimeler) oluşturmak için daha düşük düzeyli ayrıntı ve örnekleri nasıl birleştireceğini öğretir (Chang ve Ku, 2014; Cook ve Mayer, 1988). Ana fikri doğru biçimde belirlemek için şu soruları sorulabilir: "Yazarın metinde durduğu/durmak istediği asıl düşünce Nedir, Metinde hangi olaylar ya da bilgiler ana fikirle bağlantılıdır, Ana fikri anlatmayan cümleler nelerdir ve 
Metinde en önemsiz bilgiler nedir?” Bu aşamada katılımonın yeni bir metin üzerinde çeldiricileri renkli kalem kullanarak belirlemesi ve metnin ana fikrini ortaya çıkarması amaçlanır. Katılımcı ana fikirle bağlantılı cümleleri belirlemede başarılı bir performans sergilendiğinde altıncı derse geçiş yapılır.

Ders 6. 5N 1K tekniğini kullanılarak bir metnin ana fikrinin belirlenmesi. Bu adımda bir metinde tüm kanıtlayıcı ögelerin incelenmesi ele alınır. Metindeki unsurlar ve olayların akışıyla ilgili olarak $5 \mathrm{~N} 1 \mathrm{~K}$ tekniğinin kullanımının öğretimi yapılır. a) Ne oldu?, b) Ne zaman oldu?, c) Nasıl bir şey oldu?/Nasıl meydana geldi?, d) Nerede gerçekleşti?, e) Kim/Kimler rol aldı? gibi soruların cevaplarıyla ana fikir belirlenmeye çalışılır. Bu tür bir öğretim, katılımcıya metinle içsel bir diyalog geliştirerek metindeki kişiler, olaylar ve diğer ayrıntılar hakkında sorular sormayı ve bu soruların cevabını aramayı öğretmeye dayanmaktadır (Berkeley, 2007). Çünkü bu sorular okuyucunun metnin özünü taşıyan bir ana fikir beyanı oluşturmalarını içerir. Uygulamacı $5 \mathrm{~N} 1 \mathrm{~K}$ tekniğine uygun yeni bir metin seçer ve bu metinde nerede, ne zaman, neden bir şeyler yapıldığı veya bir şeyin nasıl göründüğü ayrıca kimlerin rol aldığıyla ilgili kendine sorular sorarak katılımcıya bilişsel açıdan model olur daha sonra metnin ana fikrini belirler. Diğer derslerde olduğu gibi bu derste de katılımcının bağımsız performans sergileyip sergilemediği değerlendirilir. Bunun için katılımcıya yeni bir metin verilir. Katılımcı parçayı sessiz bir şekilde okuduktan sonra $5 \mathrm{~N} 1 \mathrm{~K}$ kartını doldurmaya ve metni gözden geçirerek ana fikir cümlesini yazmaya çalışır. Uygulamacı katılımcıyla birlikte parçayı gözden geçirir ve katılımcının stratejiyi etkili bir biçimde kullanmadığıyla ilgili olarak düzeltici geri bildirimler verir.

Metin. Koyunpazarı'nda bir ufacık dükkân, bir küçük ocak yanıyor, bir ufak çocuk körük çekiyor (Öğrenciye bu kavram açıklanmıştır.) [Körük çekmek, ateşi canlandırmak için kullanılan ve açılıp kapandıkça içindeki havayı üfleyen araçtır, TDK, 2005]. İhtiyarlamış, küçülmüş, aksakallı küçük yüzlü bir adam, gözünde çifte gözlük, mini mini halkaları ateşte ısıııp zincir bağlıyordu. Ne hoş bir manzara, gözüm iliş̧i. Dükkânın önünde kaldım. Bir çilingir dükkânı. Ufak kilitler, eski zaman kapı halkaları, rezeler, menteşeler, hayvan zincirleri. Böyle ufak tefek şeyler yapıyor. Bunlardan pek çok da yapmış, dükkânın ötesine berisine asmış. [...] (Memduh Şevket ESENDAL) (Kısaltılmıştır.)

Ders 7. Ana fikir ve ayrıntı belirlemeyi değerlendirme. Bu adımda Ders 2'den Ders 6'ya kadar verilen derslerde ana fikir belirleme adımları gözden geçirilir. Bunun için uygulamacı, katılımcının ana fikir belirleme becerisini değerlendirmek için katılımcıya tüm dersteki adımları içeren bir çalışma kâğıdını verir. Çalışma kâğıdında üç paraftan oluşan çok konulu ve çoktan seçmeli ögelerin yer aldığı bir öyküleyici metin ve bu metnin paragraflarındaki konular, ana fikir ve ayrıntılar ile ilgili sorular bulunmaktadır. Katılımcıdan hedef metni dikkatlice okuması ve sorulara cevap vermesi istenir. Katılımcıya etkinliği tamamlaması için yeterince zaman verilir (genel olarak 10-15 dakika). Hedeflenen ölçüt kazanılır kazanılmaz (Doğru ana fikir ve ayrıntı belirleme yeterliliği) öğretim uygulaması sona erdirilir. Tüm katılımcılar için toplu yoklama oturumları düzenlenir. Ancak hala ana fikir belirlemede problem yaşanıyorsa uygulamanın adımlarına geri dönülür. Bu süreç diğer katılımcılar için de uygulanır.

\section{Veri Toplama Araçları}

Okuduğunu anlama değerlendirme aracı. Katılımcıların zayıf okuyucular olup olmadığını belirlemek için okuduğunu anlama becerilerini ölçmeye yönelik bir okuduğunu anlama değerlendirme aracı kullanılmıştır. Araştırmacı, katılımcı öğrencilerin düzeyine uygun çeşitli kaynakları incelemiş ve 550 kelimeden ve dört paragraftan oluşan bir öyküleyici metin belirlemiştir. Daha sonra araştırmacı bu metindeki önemli ipuçlarını, olayların akışını, şahıslar, mekân-zaman unsurlarını, metnin konusu ve ana fikrini dikkate alarak okuduğunu anlamayı sınayan bilgi (hatırlama) ve kavrama düzeyinde on iki açık-uçlu soru geliştirmiştir. Soru yönergeleri genellikle şöyledir: a) Metinde ana karakter kimdir?, b) Birinci paragrafin konusu nedir?, c) Metinde geçen olayları oluş sırasına göre sıralayınız., d) “...” sözü ile ne anlatılmak isteniyor?, e) Metnin ana fikrini yazınız. Okuduğunu anlama değerlendirme aracındaki soruların doğru yanıtları önceden öğrenilen bilgilere değil, hedef metinde okunan bilgilere doğrudan bağlıdır. 
Hazırlanan taslak araç, soruların ölçülmesi istenen cevabı ölçecek nitelikte olup olmadığına, soruların cevaplarının doğrudan metnin içerisinde geçip geçmediğine, metni anlamaya hizmet edecek tüm ögelere dair soruları taşıyıp taşımadığına, çıkarımsal türdeki soruların değerlendirilmesi amacıyla metindeki bilgi birimlerinden çıkarım yapmayı ölçüp ölçmediğine, soruların dilbilgisi kurallarına uygun olup olmadığına, hem bilgi hem de kavrama düzeyinde soru tiplerini içerip içermediğine dair uzman görüşlerine sunulmuştur. Araştırmacı, Türkçe Eğitimi bölümü iki öğretim üyesine okuma metnini ve hazırladığı soruların bir nüshasını teslim ederek bağımsız olarak değerlendirmelerini istemiştir. Değerlendirme sonucunda bazı sorularda düzenlemelere gidilmiştir. Tekrar niteliği taşıyan sorular testin kapsamından çıkartılmış ve soru köklerinde bazı düzeltmelere gidilerek değerlendirme aracına son şekli verilmiştir. Katılımcılardan hazırlanan sorulara yazılı olarak cevap vermeleri istenmiştir. Ayrıca katılımcılara yeterli zaman verilmiş ve herhangi bir tepkide (doğru veya yanlış) bulunulmamıştır. Araştırmacı, katılımcıların sorulara verdikleri cevapları, hem soruları hem de doğru yanıtları içeren puanlama kâğıdına doğrudan aktarmıştır. Katılımcıların okuduğunu anlama düzeyleri, metinle ilgili sorulan sorulara verilen doğru cevaplara göre belirlenmiştir. Soruların değerlendirilmesinde öğrencilere gerek bilgi gerekse kavramsal anlama düzeyinde soruları tam ve doğru bir şekilde cevaplayanlar için 3 puan, biraz eksiklikleri olup ancak beklenen cevabın yarısından fazlasını cevaplayanlar için 2 puan; yarısını cevaplayanlar için 1 puan, hiç doğru cevap vermeyenler için 0 puan verilmiştir. Yüzdeliği hesaplamak için alınan puanların toplamı alınması gereken puanların toplamına bölünmüştür ve öğrencinin okuduğunu anlama düzeyi tespit edilmiştir (Akyol, 2010; Yüksel, 2010). Katılımcılardan elde edilen verilerin bir kopyası okuma-yazma eğitimi ve ölçmedeğerlendirme alanında doktora yapan iki araştırma görevlisine sunulmuştur. Değerlendiriciler arası arasındaki anlaşma oranı Görüş birliği/Görüş birliği + Görüş ayrılığı x 100 formülü kullanılarak belirlenmiştir. Değerlendirme sonrasında değerlendiriciler arası güvenirlik katsayısının .84 ile .90 arasında değiştiği bulunmuştur.

Uygulamada kullanılan metinler. $\mathrm{Bu}$ çalışmada, başlama düzeyi yoklama oturumlarında, öğretim oturumlarında, toplu yoklamalarda ve izleme oturumlarında kullanılmak üzere kısa öyküleyici metinler kullanılmıştır. Öyküleyici metinlerin seçilmesinin nedeni bu tür metinlerin işlenen konu ve ana düşünceyi kavratmak için ana olayları, şahıs kadrosunu, mekânı, zamanı, çatışmaları ve çözüme ulaşma noktalarını belirlemeyi öğretmesi ve metnin hikâye haritasını çıkarmanın öğrencilerin kavrama becerilerini geliştirmek açısından faydalı olmasıdır (Karatay, 2014). Akyol'a (2011) göre öyküleyici metinler, okuyucuya anlam çıkarma, yorumlama, organize etme, problem çözme ve metnin haritasını çıkarma firsatları sunmaktadır. Ancak öyküleyici metinlerde, okuyucu olayların açıklamasından ve bunların kronolojik sıralamasından bir hikâye temasını ayırt etmek zorundadır (Williams, 2004). Okur önce olayın ne olduğunu ve kişileri tespit eder ve onları olay veya olaylar zinciriyle ilişkilendirerek kategorize eder, ardından ana düşünceye ulaşmaya çalışır (Karatay ve Okur, 2012).

Ana fikir belirleme becerisi öğretim programına dayalı olarak her bir dersle ilgili farklı kısa öyküleyici metin parçalarına yer verilmiştir. Araştırmacı, öğretmen görüşü ve öğrencilerin okuma düzeylerini dikkate alarak çeşitli ders kitapları ve yardımcı kaynaklardan yirmi kısa öyküleyici metin belirlemiştir (Akyol, Yıldırım, Ateş, Çetinkaya ve Rasinski, 2014; Dayığlu, 2015, 2016; Milli Eğitim Bakanlığı, 2016). Seçilen metinler, açık veya gizli ana fikirleri içermektedir. Araştırma için metinlerin seçiminde bu metinlerin öğrenciler açısından yeni olması hedeflenmiştir. Bunun için öğrencilerin öğretmenine danışılmıştır. Metinler, 100-580 kelime uzunluğunda ve en az bir paragraftan oluşmaktadır. Öğrencilerin kolay okuyabilmeleri için metinlerin yazımında 12 puntoluk harfler ve yazı karakteri olarak Comic Sans MS kullanılmıştır. Ayrıca öğrencilerin satır atlamadan okuyabilmelerini sağlamak için her bir metin 1.5 satır aralığıyla düzenlenmiştir.

Araştırmacılara göre deneysel uygulamalarda kullanılmak üzere seçilen metinlerin okunabilirliği önemli bir değişkendir, dolayısıyla bu metinlerin okunabilirlik düzeyinin hesaplanması gerekir (Kinder, Bursuck ve Epstein, 1992). Okunabilirlik, okuyucu tarafından metinlerin kolay veya güç anlaş1lır olma durumudur. Okunabilirlik ayrıca çoğunlukla metinlerin nicel özellikleri yani cümle ve kelime uzunlukları ve bilinmeyen kelime sayısı göz önüne alınarak metnin güçlüğünü belirlemeyi amaçlar (Ateşman, 1997). Metinler için FleschKincaid'in geliştirdiği okunabilirlik formülüyle metinlerin okunabilirlik düzeyleri hesaplanmıştır [Çok zor: 1-2.9; Zor: 3-4.9; Orta güçlük:5-6.9; Kolay:7-8.9; Çok kolay: 9-10]. Flesch-Kincaid formülü, cümle başına düşen kelime 
ve kelime başına düşen hece sayısına dayalı bir formüldür (Temur, 2003). Metinlerin ortalama okunabilirlik düzeyi Flesch-Kincaid'in okunabilirlik formülü kullanıldığında 5.3'e (en düşük 2.8 ve en yüksek 7.8 ) tekabül etmektedir. $\mathrm{Bu}$ sonuç, seçilen tüm metinlerin okunabilirlik açısından ortalama okunabilirliğe sahip olduğunu göstermektedir (Ateşman, 1997).

Bu adımdan sonra metinlerin öğrenci düzeyine uygunluğu ve eşit güçlük düzeyine sahip olup olmadığını değerlendirmek üzere araştırmacı tarafından bir "Metin Değerlendirme Rubriğgi" geliştirilmiştir. Değerlendirme rubriği metinlerin öğrenci düzeyini temsil eden toplam kelime sayısı, cümlelerin uzunluğu, dil bilgisi kuralları, metindeki ögelerin sıralanışının öykü yapısına uygunluğu, anlatımda akıcılık ve anlaşılırlık, olay, ana düşüncenin işlenmesi, kullanılan kavramların düzeye uygunluğu gibi birçok maddeden oluşmaktadır (Akyol, 2010). Değerlendirme rubriği, 4 puanlık bir likert tipi ölçekten oluşmaktadır (örn., 1=Uygun değil, 2=Uygun, 3=Oldukça uygun, 4=Mükemmel). Seçili metinler ve metin değerlendirme rubriğinin bir kopyası okuma-yazma alanında çalışmaları olan iki uzmana verilmiştir. Uzmanlardan seçilen öyküleyici metinleri bağımsız olarak Metin Değerlendirme Rubriğine göre değerlendirmeleri istenmiştir. Değerlendirme sonucunda başlangıçta seçilen yirmi metinden üçünün metnin değerlendirme rubriğindeki maddelere uygun olmadığı sonucuna varılmıştır. Geriye kalan on yedi metin için değerlendiriciler arası arasındaki anlaşma oranı Görüş birliği/Görüş birliği + Görüş ayrılığ1 x 100 formülü kullanılmıştır. Değerlendiriciler arası anlaşma \%100'e ulaşmıştır. Ayrıca seçilen metinlerin geliştirilen veri toplama araçları, ana fikir belirleme dersleri ve yoklama oturumları (başlama düzeyi, izleme ve toplu yoklamalar) için yeterli olduğu konusunda görüş birliğine varılmıştır.

Sosyal geçerlik formu. Sosyal geçerlikte bir öğretim uygulamasının ya da programının etkilerinin önemi ve sosyal kabul edilebilirliği incelenir (Wolf, 1978). Ana fikir belirleme öğretim programının sosyal geçerliliğini değerlendirmek için deneysel uygulama sonunda katılımcılarla görüşmeler gerçekleştirilmiştir. Bunun için her bir öğrenciye Jitendra ve diğerleri (1998) tarafından geliştirilen ve araştırmacı tarafından öğrenci düzeylerine yönelik olarak uyarlanan öz-bildirim memnuniyet formu verilmiştir. Öğrencilerden strateji öğretiminin etkililiğini bireysel olarak değerlendirmeleri istenmiştir. Öz-bildirim memnuniyet formu üç başlık altında toplanmıştır. Birincisi strateji öğretiminin etkililiğine ilişkin maddelerden oluşmaktadır. Bu maddeler a) Yapılan öğretim, metinlerin ana fikirlerini belirlememe yardımcı oldu, b) Ana fikir belirleme kartları ana fikir belirleme yöntemini kullanmam gerektiğini hatırlatmada bana yardımcı oldu, c) Ana fikir belirleme kartları, ana fikir belirleme yöntemini nasıl kullanılacağını hatırlatmada bana yardımcı oldu, d) Öğretim, ana fikirle bağlantılı olmayan cümleleri/bilgileri ayırt etmede bana yardımcı oldu. Katılımcılardan bu maddelere cevap verirken " $5=$ Tamamen katılıyorum", " $1=$ Hiç katılmıyorum" seçenekleri arasından birini tercih etmeleri istenir. İkincisi öğretim uygulamasının memnuniyeti hakkındadır. Bu başlık altında şu soruya yer verilmiştir. Öğretim etkinliklerinden memnun kaldınız mı? Bu soruya cevap seçenekleri ise "4=Çok memnun kaldım"; "3=Memnun kaldım"; "2=Az memnun kaldım"; "1=Hiç memnun kalmadım” şeklindedir. Bunların yanında katılımcılardan öğretim oturumları boyunca yapılan etkinlikler konusunda en çok neyi beğendiklerini paylaşmaları istenmiştir.

Kısa cevaplı sorular. Ana fikir belirleme becerisi öğretiminin katılımcıların okuduğunu anlama gelișimi üzerinde etkisini değerlendirmek için başlama evresi yoklama oturumlarında, toplu yoklamalarda ve izleme oturumlarında okuduğunu anlama ile ilgili kısa cevaplı sorular kullanılmıştır. Bu sorular öyküleyici metinlere dayalı olarak hazırlanmıştır. Katılımcıların ana fikir performansıyla bütünleştirilen okuduğunu anlama becerilerindeki gelişmeleri belirlemek için her bir yoklama oturumunda on kısa cevaplı soru üretilmiştir. Soruların 5'i metinde açık bir şekilde yer alan bilgilerle ilgili hatırlama düzeyinde sorular iken; 5'i de öğrencilerin metinden çıkarım yapmalarını ve ana fikir ve ayrıntı belirlemelerini gerektiren anlama düzeyinde sorulardır. Katılımcılardan bu sorulara yazılı olarak cevap vermeleri istenmiştir. Soruların değerlendirilmesinde öğrencilere hatırlatıcı düzeyde soruları tam ve doğru bir şekilde cevaplamaları durumunda 1 puan, kısmen doğru cevap verme durumunda 0.5 puan, hiç doğru cevap vermemeleri durumunda 0 puan verilmiştir. Anlama düzeyi sorularını tam ve doğru bir şekilde cevaplayanlar 1 puan alırken, kısmen cevap verenler yarım puan ve hiç doğru cevap vermeyenler 0 puan almıştır. Bir katılımcının kısa cevaplı sorulardan alacağı maksimum puanı10 iken minimum 
puanı 0'dır. Doğru tepki sayısı katılımcıların on soruya verdikleri doğru yanıtların sayısıyla temsil edilmiştir. Bu sayılar ile katılımcıların okuduğunu anlama düzeyleri tespit edilmiştir.

\section{Araştırma Deseni ve Uygulama}

Ana fikir belirleme becerisi öğretiminin okuduğunu anlamada güçlük çeken dördüncü sınıf öğrencilerinin okuduğunu anlama becerileri üzerindeki etkilerini belirlemek için yapılan bu çalışmada, tek denekli deneysel desenlerden deneklerarası yoklama evreli çoklu yoklama deseni kullanılmıştır (Tekin-İftar ve Kırcaali-İftar, 2015). Deneysel uygulama süreci başlama düzeyi yoklama oturumları, öğretim oturumları, toplu yoklamalar ve izleme oturumlarından oluşmaktadır.

Başlama düzeyi yoklama oturumları. Başlama düzeyi yoklama oturumları üst üste kararlı veri elde edilinceye değin sürdürülmüştür. $\mathrm{Bu}$ oturumlarda, katılımcıların öğretimi yapılacak ana fikir belirleme becerilerindeki var olan performanslarına ilişkin verileri toplamak için tek firsat yöntemi kullanılmıştır. Bunun için okuduğunu anlamayı değerlendirmeye ilişkin 10 adet kısa cevaplı soruyu içeren çalışma kâğıtları kullanılmıştır. Her oturumda farklı bir öyküleyici metin kullanılmış ve bu metinle ilgili 10 kısa cevaplı soruyu içeren çalışma kâğıtlarına yer verilmiştir. Öğrencilerden çalışma kâğıdındaki metni bağımsız olarak ve sessizce okumaları ve bununla ilgili hazırlanan soruları yazılı olarak cevaplamaları istenmiştir. Katılımcılara kısa cevaplı soruları cevaplamaları için yeterince zaman verilmiştir.

Toplu yoklamalar. Bu araştırmada bağımlı değişkene ilişkin (okuduğunu anlama gelişim düzeyi) toplu yoklamalar her bir katılımcı için yapılan öğretim oturumları sonunda gerçekleştirilmiştir. Toplu yoklamalarda, başlama düzeyi yoklamalarında izlenen sürecin aynısı izlenmiştir. Katılımcıların okuduğunu anlama başarı düzeylerini belirlemek için kendilerine yeni bir öyküleyici metin ve bu metinle ilgili hazırlanan 10 kısa cevaplı soruyu içeren çalışma kâğıtları verilmiştir. Katılımcıların kısa cevaplı soruya verdikleri doğru cevaplar belirlenmiş ve doğru tepki sayısı yüzde olarak hesaplanmıştır.

Öğretim oturumları. Ana fikir belirleme ile ilgili dersler “Doğrudan Öğretim Model” ile yürütülmüştür. Öncelikle öğrencilerin ana fikir belirleme performansı ile bütünleştirilen okuduğunu anlama becerisine ilişkin başlama düzeyi verileri toplanmıştır. Kararlı veri elde edilen ilk katılımcı ile öğretim uygulamasına başlanmıştır. Her bir öğretim oturumu katılımcılar için haftanın bir günü/günlerine ayrılan Türkçe derslerinde gerçekleştirmiştir. Her bir öğrenci ile ana fikir belirleme becerisinde ölçütün karşılanıncaya kadar öğretim oturumlarına devam edilmiştir. Hedeflenen ölçüt, katılımcıların metinlerin ana fikirlerini, paragraflarda ana fikirle bağlantılı ayrıntılarını saptamaları ve ana fikir ve ayrıntı belirleme ile ilgili okuduğunu anlama sorularına doğru cevap vermeleridir.

İzleme yoklamaları. Öğretim oturumlarının tamamlanmasından üç ve beş hafta sonra katılımcıların öğretim uygulaması sonucunda elde ettiği kazanımları hangi doğruluk düzeyinde sergilediğini ve bunları ne düzeyde koruduklarını değerlendirmek için izleme (kalıcılık) oturumları düzenlenmiştir. İzleme oturumlarında öğrencilere ana fikir belirleme becerisi, bileşenleri ve öğretimi hakkında hiçbir hatırlatma yapılmamıştır. Bu oturumlarda toplu yoklamalarda olduğu gibi katılımcılara yeni bir öyküleyici metin ve bu metin ile ilgili on kısa cevaplı soruyu içeren çalışma kâğıtları verilmiştir. Katılımcılardan metni sessizce okumaları ve çalışma kâğıdını bağımsız olarak doldurmaları istenmiştir.

\section{Güvenirlik Verilerinin Toplanması}

Bu çalışmada gözlemciler arası güvenirlik ve uygulama güvenirliğinin sağlanması için güvenirlik analizleri iki bağımsız gözlemci tarafından yapılmıştır. Birincisi, sınıf eğitimi alanında doktora yapan bir araştırma görevlisidir. İkincisi, katılımcıların sınıf öğretmenidir. Öğretmen, sınıf öğretmenliği lisans programından mezun olup on iki yıllık deneyime sahiptir. Öğretmen, araştırmanın yürütüldüğü okulda beş yıldır görev yapmaktadır. Gözlemcilerin yoklama ve öğretim oturumlarına katılımı sağlanmıştır. Gözlemciler ana fikir belirleme becerisi öğretim programı ve gözlemleyeceği davranışlar konusunda uygulama öncesi araştırmacı tarafından okulun 
seminer odasında iki oturumda bilgilendirilmiştir. Çalışmada, puanlayıcılar arası güvenirlik ve uygulama güvenirliği olmak üzere iki tür veri toplanmıştır.

Birincisi, puanlayıcılar arası güvenirliktir. Puanlayıcılar arası güvenirlik, iki gözlemcinin birbirinden bağımsız ancak eş zamanlı şekilde hedef davranışın ne düzeyde gerçekleştiğine ilişkin yaptıkları değerlendirmelerin karşılaştırılmasıdır. Gözlemciler arası güvenirlik verilerini elde etmek için tüm yoklama ve öğretim oturumlarının \%30'ında veriler toplanarak analizler yapılmıştır. Gözlemciler arası güvenirlik "Görüş birliği/ Görüş birliği + Görüş ayrılığı x 100" formülüyle (Tekin-İftar ve Kırcaali-İftar, 2015) hesaplanmıştır. Gözlemciler arası güvenirlik toplu yoklamalarda $\% 88$, öğretim oturumlarında ise $\% 92$ olarak bulunmuştur. İkincisi, uygulama güvenirliğidir. Bu adımda, uygulamacının yürüttüğü öğretim uygulamasının hazırlanan uygulama planına ne ölçüde uygunluk gösterdiği belirlenmektedir. Bu amaçla uygulama planında gerçekleşmesi beklenen uygulamacı davranışları belirlenir ve bir "Uygulama Güvenirliği Formu" hazırlanır. Bir veya birden fazla gözlemci öğretim uygulamasının uygulamacı davranışlarını içerip içermediğini hazırlanan uygulama güvenirliği formuna işaretler (Tekin-İftar ve Kırcaali-İftar, 2015). Uygulamanın güvenirliği için bu çalışmada uygulamacı davranışlarına ilişkin bir kontrol listesi hazırlanmıştır. Bu davranışlar bir dizi "Doğrudan Öğretim Modelinin" adımlarını içermektedir (Ellis ve diğ., 1991). Bunlar a) Yöntemin tanımlanması (Ana fikir kavramı, önemi ve faydaları), b) Yöntemin modellenmesi, c) Sözel detaylandırma ve tekrarlamalar (Yöntemin bileșenlerini sözlü bir biçimde detaylandırma ve tekrar etme), d) Yöntemin kazanımı (Rehberli uygulamalar ya da uygulama kazanımı), e) Bağımsız uygulamalar ve f) Yöntemi değerlendirme şeklindedir. Gözlemciler, öğretim oturumlarının \%30'unu izlemiş ve kendilerine verilen uygulama güvenirliği veri kontrol listesindeki maddeleri işaretlemiştir. Uygulamanın güvenirlik analizinde Billingsley, White ve Munson (1980) tarafından geliştirilen formül kullanılmıştır [(Gözlenen araştırmacı davranışı/Planlanan araştırmacı davranış1) x100]. Uygulama güvenirlik katsayıs1 \%89 olarak bulunmuştur.

\section{Verilerin Analizi}

Ana fikir belirleme becerisi öğretiminin etkililiğine ilişkin elde edilen veriler grafiksel analiz yoluyla analiz edilmiştir. Etki büyüklükleri Parker, Vannest ve Brown (2009) tarafindan geliştirilen "İyileştirme oran farkı" (Öğretim oturumları ortalaması[\%] - Başlama evresi ortalaması [\%]=İyileştirme oranı farkı) kullanılarak hesaplanmıştır. İyileştirme oranının hesaplanmasında başlama düzeyi ve öğretim oturumlarında katılımcıların başarılı performanslarındaki fark ortaya çıkarılır. Her yoklama için iyileştirme oranı, gelişmiş veri noktalarının sayısı bu yoklamalardaki toplam veri noktalarına bölünmesi olarak tanımlanır. Parker ve diğerlerine (2009) göre iyileştirme oranı farkının .71 üzerinde olması uygulamanın büyük bir etkiye işaret ettiğini gösterir; .50 ila .70 arası orta bir etkiye işaret eder ve .50 'inin altında olması küçük etkilere işaret eder. Etki büyüklügünü belirlemek için her bir katılımcının başlama düzeyi yoklamaları ve öğretim oturumları sonunda yapılan toplu yoklamalar arasındaki çakışmayan veriler arasındaki fark hesaplanmıştır. Çalışmada sosyal geçerlik verileri ise katılımcılara verilen öz-bildirim memnuniyet formundan elde edilmiş ve elde edilen veriler betimsel olarak analiz edilmiştir. Grafik üzerindeki eğriler arasındaki fark yorumlanarak bağımsız değişkenin bağımlı değişken üzerinde etkisinin olup olmadığına bakılmıştır. Şekil 2' de yatay eksen, ana fikir belirleme becerisi öğretimi programının öğretim ve toplu yoklamalarda (başlama düzeyi, toplu yoklama ve izleme) gerçekleştirilen oturum sayılarını, düşey eksen ise bu evrelerde her üç katılımcının toplu yoklamalarda okuduğunu anlama ile ilgili hazırlanan kısa cevaplı sorulara verdikleri doğru tepki sayılarını ifade etmektedir.

\section{Bulgular}

Bu çalışmada, bir ilkokulun dördüncü sınıfinda öğrenim gören ve okuduğunu anlama becerilerinde zayıf düzeyde olduğu saptanan üç öğrenciye ana fikir belirleme becerisi öğretim programı uygulanmış ve öğretim programının öğrencilerinin okuduğunu anlama gelişimi üzerindeki etkileri değerlendirilmiştir. Elde edilen sonuçlara göre başlama düzeyi yoklama oturumlarında, Kadir'in on kısa cevaplı soruya verdiği doğru yanıtların ortalaması 2.66 'dır. Ana fikir belirleme becerisi ile verilen öğretim uygulaması tamamlandıktan sonra yapılan toplu yoklamalarda Kadir'in kısa cevaplı sorulara verdiği doğru cevapların ortalaması 8.25 olarak bulunmuştur. 
$\mathrm{Bu}$ sonuca göre Kadir'in doğru cevap sayısında artış gözlenmiştir. İzleme verileri öğretim oturumları tamamlamadıktan sonra üçüncü ve beşinci haftalarda düzenlenen izleme yoklamaları ile elde edilmiştir. Bu oturumlarda katılımcıların okuduğunu anlama performansını değerlendirmek için başlama düzeyi yoklama oturumlarında ve toplu yoklamalarda olduğu gibi öyküleyici metinler ile ilgili on kısa cevaplı soru hazırlanmıştır. Öğretim programının uygulanmadığı izleme oturumlarında Kadir'in kısa cevaplı sorulara verdiği doğru yanıtların ortalaması 8.5 olarak bulunmuştur. Başlama düzeyiverilerine göre Kadir elde ettiği becerileri uygulama sona erdikten sonra koruyup sürdürmede kararlılık göstermiştir. Kadir ile hedeflenen ölçüt karşılandıktan sonra gerçekleştirilen ilk toplu yoklamaların ardından Ayşe ile üst üste kararlı veri elde edildiği için ana fikir belirleme becerisi öğretimine geçilmiştir. Başlama düzeyi yoklama oturumları sonuçları incelendiğinde, Ayşe'nin kısa cevaplı sorulara verdiği doğru yanıtların ortalaması 2.25 'tir. Öğretim oturumları sonunda gerçekleştirilen toplu yoklamalarda, Ayşe'nin doğru yanıtların ortalaması 8.0 olarak bulunmuştur. Ayşe'nin elde ettiği kazanımlarını koruyup korumadığını belirlemek için yapılan izleme oturumlarında Ayşe'nin ortalaması 8.25 olarak belirlenmiştir. Bu sonuç, Ayşe'nin hedeflenen ölçütü koruduğunu göstermektedir. Ayşe ile hedeflenen ölçüt karşılandıktan sonra yapılan bir sonraki toplu yoklamaların ardından üçüncü katılımcı Erkan ile kararlı veri elde edildiği için öğretim oturumlarına geçilmiştir. Erkan'ın başlama düzeyi yoklama oturumlarında kısa cevaplı sorulara verdiği doğru yanıtların ortalaması 1.2'dir. Öğretim oturumlarının sonunda yapılan toplu yoklamalarda Erkan'ın doğru yanıtların ortalaması 8.25 olarak bulunmuştur. İzleme oturumları verileri incelendiğinde, Erkan'ın performansı 8.5olarak belirlenmiştir. Bu sonuca göre Erkan diğer katılımcılar gibi ana fikir belirleme becerisini uygulama bitiminden sonra korumaya devam etmiştir. Katılımcılar için etki büyüklüklüleri sırasıyla $.87, .93$ ve .74' tür. Bu değerler, öğretim programının katılımcıların okuduğunu anlama gelişimi üzerinde büyük bir etkiye sahip olduğunu gösterir (Parker ve diğ., 2009).

Sosyal geçerlik formunda ana fikir belirleme becerisi öğretiminin etkililiğine ilişkin öğrenci puanları incelendiğinde, Ayşe için ortalama 3.6, Kadir için 4.1 ve Erkan için 2.9 olarak ortaya çıkmıştır. Katılımcılara yapılan öğretim uygulaması hakkında memnuniyetleri sorulduğunda, öğrencilerin yöntemin memnuniyeti hakkında yaptıkları değerlendirmeler sırasıyla Kadir için “çok memnun kaldım”, Ayşe için "çok memnun kaldım”, Erkan için "memnun kaldım" olarak belirlenmiştir. Açık-uçlu sorular kapsamında öğrencilerin cevaplarında öğretim uygulamasının olumlu bir etkisinin olduğu görülmüştür. Örneğin Ayşe bir metnin ana fikrini bağımsız olarak belirleyebildiğini, okumaya yönelik olumlu bir tutum geliştirdiğini ve uygulamada ana fikir kartlarını beğendiğini paylaşmıştır. Kadir ise ana fikir kartındaki unsurları kullanarak okuduğu bir metinde ana fikri belirlemede ve en önemli bilgileri ayırt etmede artık başarılı olduğunu ayrıca ana fikir belirlemenin okuma sürecinin en önemli bir parçası olduğunu dile getirmiştir. Erkan ise ana fikir belirlemeyi öğrenmekten mutluluk duyduğunu paylaşmıştır. 


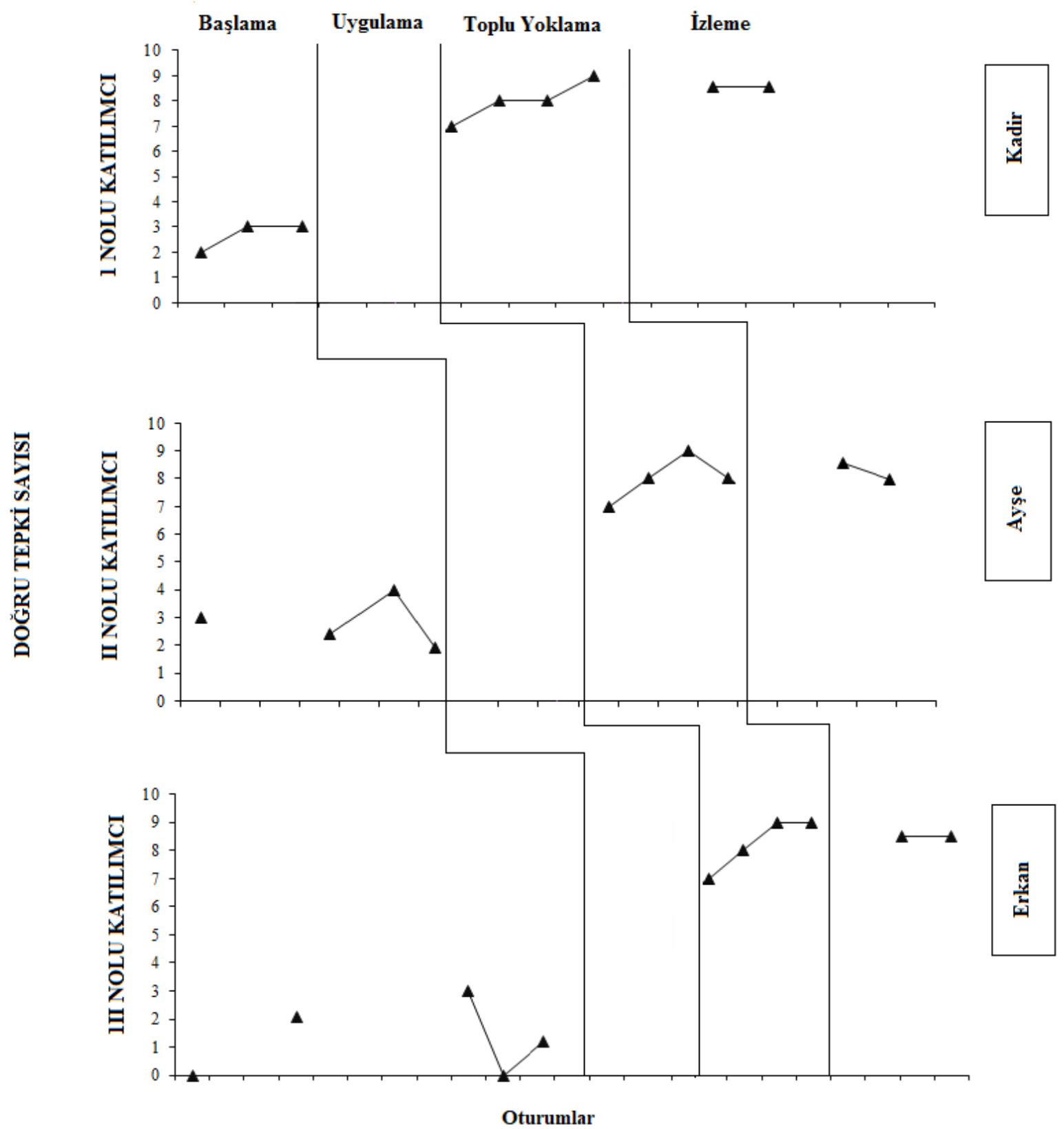

Şekil 2. Katılımcıların başlama düzeyi, toplu yoklama ve izleme oturumlarında kısa cevaplı sorulara verdiği doğru cevapların dağılımları.

\section{Tartışma, Sonuç ve Öneriler}

Araştırmada elde edilen sonuçlar, doğrudan öğretim modeli kullanılarak yapılan ana fikir belirleme becerisi öğretiminin okuduğunu anlama yönüyle zayıf düzeyde olduğu tanımlanan öğrencilerin okuduğunu anlama becerilerini geliştirdiğini göstermiştir. Katılımcılar, başlangıçtan toplu yoklama durumuna kadar öğrendiği 
becerileri kullanarak okuduğunu anlama becerilerinde belirgin iyileşmeler kaydetmiştir. Örneğin Kadir'in başlama düzeyi performansı 10 üzerinden 2.66 iken bu değer uygulama sonunda 8.25 olmuştur. Ayşe, başlama evresinden itibaren toplu yoklamalara kadar kısa cevaplı sorulara verdiği doğru yanıtlarda istikrarlı bir artış göstermiştir (2.25'e karşı 8.0). Erkan için sonuçlar incelendiğinde, Erkan'ın başlama evresinde doğru yanıtlarının ortalaması 1.2 iken toplu yoklamalarda bu değer 8.25 olmuştur. Uygulama oturumlarının sona ermesinden sonra gerçekleştirilen izleme oturumlarında her üç katılımcının kazanımlarını koruduğu belirlenmiştir. Başlama evresi yoklama oturumları verilerine göre ögretim sona erdikten sonra yapılan izleme oturumlarında her üç katılımcı uygulama yoluyla ettiği becerileri sürdürmede kararlılık göstermiştir. Bu da doğrudan öğretim yoluyla yapılan ana fikir belirleme becerisi öğretiminin okuduğunu anlama becerilerinin geliştirilmesinde etkili olduğunu göstermektedir. Sosyal geçerlilik formuna verilen bireysel cevaplar, katılımcıların ana fikir belirleme becerisi öğretimi için genel olarak olumlu yanıt verdiklerini ortaya koymuştur. Öğrenci görüşlerinde uygulama yönteminin öğrencilerin memnuniyet algısını etkilediği ve okuduğunu anlama yeteneğini geliştirmede etkili bulunduğu tespit edilmiştir. Öğrenciler metinlerde ana fikirleri nasıl belirleyeceklerini ve ana fikri destekleyen ayrıntıları nasıl işleyeceklerini öğrendiklerini belirtmiştir. Araştırma bulguları, ana fikir belirleme becerisi öğretiminin metinlerde belirli örneklerden ana fikirleri, temaları ve yardımcı düşünceleri belirlemede veya metni anlamak için gerekli bilgiyi işleme sürecinde öğrencilerin okuduğunu anlama başarısını yüksek düzeyde artırdığını doğrulamıştır. Bu bulgu, okuma üzerine bilişsel strateji öğretiminin öğrencilerin bilgiyi daha etkili ve verimli bir şekilde işlemesine ve okuduğunu anlama performansının artırılmasına yardımcı olduğu görüşünü desteklemektedir (Katims ve Harris, 1997)

Elde edilen bulgular, ana fikir belirleme performansıyla bütünleştirilen okuduğunu anlama öğretim programına dair geçmişte yapılan araştırmaların sonuçlarıyla benzerlik göstermektedir. Araştırmalar öğrencilere ana fikir belirleme becerisi öğretiminin onların okuduğunu anlama becerilerini geliştirdiğini göstermiştir (Gajria ve Salvia, 1992; Graves, 1986; Jacobowitz, 1990). Kontrol grubu kullanan çalışmaların hepsinde ana fikir öğretimi verilen deney grubunda geleneksel okuma uygulamaları verilen kontrol grubundan (yani paragrafları okuma, anlama sorularını cevaplama, cevapları gözden geçirme vb.) okuduğunu anlamada önemli ölçüde daha fazla gelişmeler gözlenmiştir (Bakken, Mastropieri ve Scruggs, 1997; Jitendra ve diğ., 2000; Kuşdemir ve Güneş, 2014; Malone ve Mastropieri, 1992; Stevens ve diğ., 1991). Örneğin Pilten (2007) çalışmasında, okuma ödevlerinde ana fikri belirleme becerisi öğretimini alan deney grubunun geleneksel okuma öğretimine dâhil olan kontrol grubu öğrencilerine kıyasla metinlerde daha fazla ana fikir cümlelerini belirlediği tespit edilmiştir. Okuduğunu anlama stratejileri üzerine yapılan diğer çalışmalar, ana fikir ve detayların bilincine varılmasında ve okuduğunu anlama becerilerinin geliştirilmesinde strateji öğretiminin pratik yararlılı̆̆ını doğrulamıştır (Ellis ve Graves, 1990; Hagaman, Casey ve Reid, 2016; Hagaman ve Reid, 2008; İlter, 2017a; Lauterbach ve Bender, 1995). Bu sonuçlara göre okuduğunu anlama stratejileri üzerine yapılan doğrudan öğretimin zayıf okuyucuların okuduğunu anlamalarına aracılık ettiği söylenebilir.

Araştırmada elde edilen sonuçlar ana fikir belirleme becerisi üzerine yapılan öğretimin ana fikir belirleme becerilerini öğrenme konusunda bütün katılımcılara katkı sağladığını göstermiştir. Ancak bu çalışmanın bazı sınırlılıkları vardır. Birincisi, katılımcı sayısı üç dördüncü sınıf öğrencisiyle sınırlıdır. Bulguların genellenebilmesi için farklı sınıf düzeylerindeki farklı katılımcılarla tekrarlanmasına gereksinim vardır. İkincisi, örneklem seçiminde araştırmacı geliştirdiği okuduğunu anlama değerlendirme aracı sonuçlarını dikkate alarak okuduğunu anlama yönüyle zayıf düzeyde olduğu belirlenen öğrencileri hedef almıştır. Gelecek çalışmalar öğrencilerin hem kelime tanıma/kelimeyi okumayı hem de okuduğunu anlama becerilerini değerlendirmeyi içeren ölçümleri ele alabilir. Üçüncüsü, ana fikir öğretim programı üç katılımcı ile bire bir olarak yürütülmüştür. Gelecek çalışmalarda, uygulamanın küçük grup ya da tüm sınıf ortamında eşit derecede etkili olup olmayacağı belirlenebilir. Dördüncüsü, ögretim programının katılımcıların okuduğunu anlama gelişimi üzerinde etkisini belirlemek için tüm yoklama ve öğretim oturumlarında öyküleyici metinler kullanılmıştır. Öyküleyici metinlerin kullanılmasının sebebi bu tür metinlerin ana fikrini kavratmak için olaylar, şahıslar, zaman, mekân unsurlarını ve çözüme ulaşma noktalarını belirlemeyi öğretmeye ve metnin hikâye haritasını çıkarmak için öğrenciler açısından hem eğlenceli hem de okuduğunu anlamaya yardımcı olmasıdır (Karatay, 2014). Ancak okuma öğretimi üzerine çalışan araştırmacılar 
açıklayıcı metinlerin anlaşılmasına daha fazla önem verilmesi gerektiğine dikkat çekmiştir (Williams, 1986). Çünkü zayıf okuyucular için açıklayıcı metinleri okuma öyküleyici metinleri okumaktan çok daha zor ve karmaşıktır. Ayrıca ana fikirlerin belirlenmesindeki sorunlar açıklayıcı metinler dikkate alındığında daha belirgin hale gelmektedir (Williams, 2005). Gelecek çalışmalar, açıklayıcı metinler kullanılarak ana fikir belirleme becerisi öğretimini ele alabilir. Beşincisi, katılımcıların öğrendiği ana fikir belirleme becerisini yeni durum veya farklı içeriklerde performansa dönüştürüp dönüştürmeyeceğine dair değerlendirmeler (genelleme yoklamaları) yapılmamıştır. Gelecekte araştırmacılar katılımcıların ana fikir belirleme becerisi öğretimi yoluyla elde ettikleri kazanımları farklı içeriklere veya bilimsel metinlere genelleyip genellemediğine ilişkin çalışmaları yürütebilir. Çünkü zayıf okuyucuların öğrendikleri stratejileri nasıl kullandıkları ya da genelleyebildiklerini etkin bir şekilde takip etmelerini incelemek önem arz etmektedir (Graves, 1986). Son olarak u çalışmada bir diğer sınırlık sosyal geçerlik verilerinin sadece öğrencilerden toplanmış olmasıdır. Gelecek araştırmalarda yapılacak uygulamalara ilişkin öğretmenler, uygulamacılar gibi farklı kişilerden de sosyal geçerlik verilerinin toplanması önerilebilir. Tüm bulgular gelecekteki araştırmalarda farklı öğrenci popülasyonları ve öğrenme ortamları için ele alınmaya ve farklı okuma değişkenleri ile genişletilmeye çalışılmalıdır.

Araştırmanın sonuçları ana fikir belirleme becerisi öğretim uygulamasının öğrencilerin okuduğunu anlama yeteneklerini geliştirdiğini göstermektedir. Bulgular, öğretim uygulamasının öyküleyici metinlerde ana fikirleri ve ana fikri destekleyen ayrıntıları belirleme ve öğrenilen becerilerin kalıcılığını sürdürme konusunda her üç katılımcıya katkı sağladığını ve başlama evresine kıyasla daha yüksek düzeyde okuduğunu anlama performansı elde edildiğini göstermiştir. Katılımcılar başlama evresinden öğretim oturumları sonunda yapılan toplu yoklamalara kadar öğrendiği becerileri kullanarak okuduğunu anlama becerilerinde belirgin gelişmeler kaydetmiştir. Geçmiş araştırmalarda olduğu gibi bu çalışmanın sonuçları da, okuduğunu anlamada güçlük çeken öğrencilere ana fikir belirleme becerilerini kazandırması bakımından umut vericidir. Bulgular ayrıca öğrencilerin okuduğunu anlama becerilerini geliştirmelerine yardım etme noktasında doğrudan öğretim şekli olarak yapılandırılmış öğretimin önemini de göstermiştir. Öğretim oturumları çok kısa sürdüğü için öğretmenlerin sınıflarında zayıf okuyucuların okuduğunu anlama performansını geliştirmelerinde ana fikir öğretimini kullanmaları basit ve pratik olabilir. Yapılandırılmış ana fikir belirleme öğretimi öğrencilerin etkili okuduğunu anlama becerilerini öğrenmesine yardım etmek için güçlü pedagojik etkilere sahiptir. Buna göre ana fikir belirleme becerisi öğretimi genel eğitim sınıflarındaki öğrenciler için okuma ve anlama sürecinde bir yol haritası olarak adlandırılabilir (Pressley ve McCormick, 1995). Bununla birlikte sosyal bilgiler veya fen gibi içerik alan sınıflarında okuduğunu anlamada problem yaşayan öğrencilerle çalışan branş öğretmenleri içerik alan metinlerini kullanarak anlam kurma becerileri konusunda doğrudan öğretim yoluyla öğrencilerinin okuduğunu anlama güçlüklerini giderebilirler ya da performanslarını artırabilirler. Çünkü içerik alan sınıflarında pek çok öğrencinin metinsel materyalleri anlama sorunları yaşadığı iyi bilinmektedir (Carriedo ve Tapia, 1996; Massey ve Heafner, 2004). Öğretmenler kendi branşlarında öğrencilere bir dizi belirli okuma stratejilerini öğreterek onların ana fikirleri belirlemelerine veya üretmelerine, gereksiz bilgileri ortadan kaldırarak etkili notlar çıkarmalarına, okurken kendi kavramlarını geliştirmelerine ve okuma stratejileri kullanımının farkında olmalarına yardımcı olabilirler. $\mathrm{Bu}$ durum öğrencilerin gelecekte daha bağımsız, yetkin ve daha eleştirel okuyucular olmalarına da hizmet edebilir (Jitendra ve Gajria, 2011). 
Kaynaklar

Aktaş, Ş., \& Gündüz, O. (2001). Yazılı ve sözlü anlatım [Written and oral expression]. Ankara: Akçă̆ Yayıncılık.

Akyol, H. (2010). Türkçe ilkokuma yazma öğretimi [Teaching Turkish first literacy]. Ankara: Pegem Akademi Yayıncilik.

Akyol, H. (2011). Yeni programa uygun Türkçe öğretim yöntemleri [Turkish teaching methods appropriate to the new program]. Ankara: Pegem Akademi Yayıncılık.

Akyol, H., Yıldırım, K., Ateş, A., Çetinkaya, Ç., \& Rasinski, T. V. (2014). Okumayı değerlendirme [Reading assessment]. Ankara: Pegem Akademi Yayıncılık.

Alfassi, M. (2004). Reading to learn: Effects of combined strategy instruction on high school students. Journal of Educational Research, 97(4), 171-184.

Ateşman, E. (1997). Türkçede okunabilirliğin ölçülmesi [Measurement of readability in Turkish]. Dil Dergisi, 58, 71-74.

Atkinson, R. C., \& Shiffrin, R. M. (1968). Human memory: A proposed system and its control processes. In K. W. Spence \& J. T. Spence (Eds.), The psychology of learning and motivation: Advances in research and theory (Vol. 2, pp. 89-195). New York: Academic Press.

Aulls, M. W. (1986). Actively teaching main idea skills. In J. Boumann (Ed.), Teaching main idea comprehension (pp. 96-129). International Reading Association, Newark, Delaware.

Bakken, J. P., Mastropieri, M. A., \&Scruggs, T. E. (1997). Reading comprehension of expository science material and students with learning disabilities: A comparison of strategies. The Journal of Special Education, 31(3), 300-324.

Beck, J. S., Buehl, M. M., \& Barber, A. T. (2015). Students perceptions of reading and learning in social studies: A multi-method approach. Middle Grades Research Journal, 10(2), 1-16.

Berkeley, S. (2007). Reading comprehension instruction for students with learning disabilities. In T. E. Scruggs \& M. A. Mastropieri (Eds.), Advances in learning and behavioral disabilities: Vol. 20, International perspectives (pp. 79-99). Oxford, UK: Elsevier.

Biancarosa, C., \& Snow, C. E. (2006). Reading next: A vision for action and research in middle and high school literacy. A report to Carnegie Corporation of New York (2nd ed.). Washington, DC: Alliance for Excellent Education.

Billingsley, F., White, O. R., \& Munson, R. (1980). Procedural reliability: A rationale and an example. Behavioral Assessment, 2(2), 229-241.

Brown, A. L., \& Day, J. D. (1983). Macro rules for summarizing texts: The development of expertise. Journal of Verbal Learning and Verbal Behavior, 22(1), 1-14.

Brown, A. L., Palincsar, A. S., \& Armbruster, B. B. (1984). Instructing comprehension-fostering activities in interactive learning situations. Anderson, R., Ruddell, R. B., \& Unrau, N. J.(Eds.), Theoretical models and processes of reading (5th ed.) (pp. 778-809). Library of Congress Cataloging-in-Publication Data.

Burke, L. (2012). Reading practices in social studies classrooms: Teacher support for middle-school students with ASC (Unpublished doctoral dissertation). Northern Illinois University.

Carnine, D. W., Silbert, J., \& Kame’enui, E. J. (1997). Direct instruction reading (3rd ed.). Upper Saddle River, NJ: Merrill. 
Carnine, D. W., Silbert, J., Kame'enui, E. J., \& Tarver, S. G. (2010). Direct instruction reading (5th ed.). Upper Saddle River, NJ: Merrill Pearson.

Carriedo N., \& Tapia J. A. (1996). Main idea comprehension: Training teachers and effects on students. Journal of Research in Reading, 19(2), 128-153.

Chang, W. C., \& Ku, Y. M. (2014). The effects of notetaking skills instruction on elementary students' reading. Journal of Educational Research, 108(4), 278-291.

Cook, L. K., \& Mayer, R. E. (1988). Teaching readers about the structure of scientific text. Journal of Educational Psychology, 80(4), 448-456.

Cox, B. D. (1997). The rediscovery of the active learner in adaptive contexts: A developmental-historical analysis of transfer of training. Educational Psychologist, 32(1), 41-55.

Çetinkaya, Ç., Ateş, S., \& Yıldırım, K. (2013). Anlam kurmanın zor ve önemli bir becerisi: Ana fikri bulma [Difficult and curial skill in making meaning: Finding main idea]. Journal of Theory \& Practice in Education, 9(3), 188-210.

Dayığlu, G. (2016). Suna'nın serçeleri [Suna's sparrows] (42. baskı): Çocuk Romanı.

Dayığlu, G. (2015). Fadiş [Fadis] (31. Baskı). İstanbul: Altın Kitaplar Yayınevi.

Deshler, D. D., \& Lenz, B.K. (1989). The strategies instructional approach. International Journal of Disability, Development, and Education, 36(3), 203-224.

Duffelmeyer, F. A. \& Duffelmeyer, B. B. (1991). Topic and main idea: Clearing up the confusion. The Reading Teacher, 45(3), 252-253.

Ellis, E. S., \& Graves, A. W. (1990). Teaching rural students with learning disabilities: A paraphrasing strategy to increase comprehension of main ideas. Rural Special Education Quarterly, 10(2), 2-10.

Ellis, E. S., Deshler, D. D., Lenz, B. K., Schumaker, J. B., \& Clark, F. L. (1991). An instructional model for teaching learning strategies. Focus on Exceptional Children, 23(6), 1-24.

Fordham, N. W., Wellman, D., \& Sandmann, A. (2002). Taming the text: Engaging and supporting students in social studies readings. Social Studies, 93(4), 149-159.

Gajria, M., \& Salvia, J. (1992). The effects of summarization instruction on text comprehension of students with learning disabilities. Exceptional Children, 58(6), 508-516.

Garner, R. (1990). When children and adults do not use learning strategies: Toward a theory of settings. Review of Educational Research, 60(4), 517-529.

Gathercole, S. E., Durling, E., Evans, M., Jeffcock, S., \& Stone, S. (2007). Working memory deficits in laboratory analogues of activities. Applied Cognitive Psychology, 22(9), 1019-1037.

Graves, A. W. (1986). Effects of direct instruction and meta-comprehension training on finding main ideas. Learning Disabilities Research, 1(2), 90-100.

Guthrie, J. T. (2008). Reading motivation and engagement in middle and high school. In J. T. Guthrie (Ed.), Engaging adolescents in reading (pp. 1-16). Thousand Oaks, CA: Corwin Press.

Güneş, F. (2000). Okuma-yazma öğretimi ve beyin teknolojisi [Literacy teaching and brain technology] (2 bask1). Ocak Yayınları.

Hagaman, J. L., \& Reid, R. (2008). The effects of the paraphrasing strategy on the reading comprehension of middle school students at risk for failure in reading. Remedial and Special Education, 29(49), 222-234. 
Hagaman, J. L., Casey, K. J., \& Reid, R. (2016). Paraphrasing strategy instruction for struggling readers, preventing school failure. Alternative Education for Children and Youth, 60(1), 43-52.

Halladay, J. L. (2012). Revisiting key assumptions of the reading level framework. The Reading Teacher, 66(1), 53-62.

Hennings, D. G. (1991). Essential reading: Targeting, tracking, and thinking about main ideas. Journal of Reading, 34(5), 348-351.

Ilter, I. (2017a). Improving the reading comprehension of primary-school students at frustration-level reading through the paraphrasing strategy training: A multiple-probe design study. International Electronic Journal of Elementary Education, 10(1), 147-161.

Ilter, I. (2017b). Teaching word meanings to students at different reading ability: A controlled assessment of the contextual-based vocabulary instruction on reading comprehension. Education and Science, 42(190), 437463.

Jacobowitz, T. (1990). AIM: A metacognitive strategy for constructing the main idea of text. Journal of Reading, 33(8), 620-624.

Jitendra, A. K., \& Gajria, M. (2011). Main idea and summarization instruction to improve reading comprehension. In R. E. O’Connor \& P. F. Vadasy (Eds.), Handbook of reading interventions (pp. 198-219). The Guilford Press New York London.

Jitendra, A. K., Cole, C. L, Hoppes, M. H., \& Wilson, B. (1998). Effects of a direct instruction main idea summarization program and self-monitoring on reading comprehension of middle school students with learning disabilities. Reading \& Writing Quarterly, 14(4), 379-396.

Jitendra, A. K., Hoppes, M. K., \& Xin, Y. P. (2000). Enhancing main idea comprehension for students with learning problems. The Journal of Special Education, 34(3), 127-139.

Just, M., \& Carpenter, P. A. (1992). Capacity theory of comprehension: Individual differences in working memory. Psychological Review, 99(1), 122-149.

Karataş, T. (2004). Edebiyat terimleri sözlüğü [Dictionary of literary terms]. Ankara: Akçă̆ Yayınları.

Karatay, H. (2014). Okuma eğitimi: Kuram ve uygulama [Reading education: Theory and practice]. Ankara: Pegem Akademik Yayınevi.

Karatay, H., \& Okur, S. (2012). Öğretmen adaylarının öyküleyici ve bilgilendirici metinleri özetleme becerileri [Prospective teachers' summarizing skills in narrative and expository texts]. The Journal of Academic Social Science Studies, 5(7), 399-420.

Kathleen M. L. (2015). Determining the main idea: Instructional strategies that work. Kappa Delta Pi Record, 51(3), 138-142.

Katims, D. S., \& Harris, S. (1997). Improving the reading comprehension of middle-school students in inclusive classrooms. Journal of Adolescent and Adult Literacy, 41(2), 116-123.

Kiewra, K. A. (1987). Note taking and review: The research and its implications. Instructional Science, 16(3), 233-249.

Kiewra, K. A., \& DuBois, N. F. (1998). Learning to learn: Making the transition from student to life-long learner. Prentice Hall. Allyn and Bacon.

Kinder, D., Bursuck, B., \& Epstein, M. (1992). An evaluation of history textbooks. Journal of Special Education, 25(4), 472-491. 
Kintsch, W., \& van Dijk, T. A. (1978). Toward a model of text comprehension and production. Psychological Review, 85(5), 363-394.

Klingner, J. K., Vaughn, S., \& Schumm, J. S. (1998). Collaborative strategic reading during social studies in heterogeneous fourth-grade classrooms. The Elementary School Journal, 99(1), 3-22.

Kuhn, M., \& Stalh, A. (1998). Teaching children to learn word meanings from context: A synthesis and some questions. Journal of Literacy Research, 30(1), 119-138.

Kuşdemir, Y., \& Güneş, F. (2014). Doğrudan öğretim modelinin okuduğunu anlama becerilerine etkisi [The effect of direct instruction model on reading comprehension skills]. Mehmet Akif Ersoy Üniversitesi Eğitim Fakültesi Dergisi, 1(32), 86-113.

Lauterbach, S. L., \& Bender, W. M. (1995). Cognitive strategy instruction for reading comprehension: A success for high school freshmen. High School Journal, 79(1), 58-64.

Malone, L. D., \& Mastropieri, M. A. (1992). Reading comprehension instruction: Summarization and selfmonitoring training for students with learning disabilities. Exceptional Children, 58(3), 270-279.

Mariotti, A. S., \& Homan, S. P. (2001). Linking reading assessment to instruction: An application work text for elementary classroom teachers (3rd ed.). Mahwah, NJ: Lawrence Erlbaum Associates.

Massey, D., \& Heafner, T. (2004). Promoting reading comprehension in social studies. Journal of Adolescent \& Adult Literacy, 48(1), 26-40.

Milli Eğitim Bakanlığı. (2016). Illkokul 4. sınıf Türkçe ders kitabı [Primary School $4^{\text {th }}$-grade Turkish Textbook]. Ankara: MEB Yayınları Ders Kitapları Dizisi.

National Reading Panel [NRP]. National Institute of Child Health, \& Human Development (US). (2000). Report of the national reading panel: Teaching children to read: An evidence-based assessment of the scientific research literature on reading and its implications for reading instruction: Reports of the subgroups. National Institute of Child Health and Human Development, National Institutes of Health. Erişim 22.10.217 https://www1.nichd.nih.gov/publications/pubs/nrp/Documents/report.pdf

Oxford, R. L. (1990). Language learning strategies: What every teacher should know. Boston: Heinle \& Heinle.

Parker, R. I., Vannest, K. J., \& Brown, L. (2009). The improvement rate difference for single case research. Exceptional Children, 75(2), 135-150.

Peverly, S. T., \& Sumowski. J. F. (2012). What variables predict quality of text notes and are text notes related to performance on different types of tests. Applied Cognitive Psychology, 26(1), 104-117.

Pilten. G. (2007). Ana fikir bulma stratejisi ögretiminin ana fikir bulma ve okuduğunu anlamaya etkisi [The effect of main idea strategy instruction on finding main idea and reading comprehension] (Yayımlanmamış doktora tezi). Gazi Üniversitesi, Eğitim Bilimleri Enstitüsü, Ankara.

Pitcher, S. M., Albright, L. K., DeLaney, C. J., Walker, N. T., Seunarinesingh, K., Mogge, S., \& Dunston, P. J. (2007). Assessing adolescents' motivation to read. Journal of Adolescent \& Adult Literacy, 50(5), 378-396.

Pressley, M. (2002). Reading instruction that works: The case for balanced teaching (2nd ed.). New York: Guildford Press.

Pressley, M., \& McCormick, C. B. (1995). Advanced educational psychology for educators, researchers, and policy makers. New York: Harper-Colli. 
Rafoth, M. A., Leal, L., \& Defabo, L. (1993). Strategies for learning and remembering: Study skills across the curriculum. Washington DC: National Education Association.

Rand Reading Study Group. (2002). Reading for understanding: Toward an $R$ \& $D$ program in reading comprehension. Santa Monica: Library of Congress Cataloging-in-Publication Data.

Reid, R., Lienemann, T. O., \& Hagaman, J. L. (2013). Strategy instruction for students with learning disabilities. New York, NY: Guilford Press.

Roberts, G., Torgesen, J. K., Boardman, A., \& Scammacca, N. (2008). Evidence-based strategies for reading instruction of older students with learning disabilities. Learning Disabilities Research \& Practice, 23(2), 63-69.

Roehler, R. L. \& Cantlon, D. C. (1997). Scaffolding: A powerful tool in social constructivist classrooms. In K. Hogan, \& M. Pressley (Eds.), Scaffolding student learning: Instructional approaches and issues. Brookline Books, Cambridge.

Samuelstuen, M. S., \& Bråten, I. (2005). Decoding, knowledge, and strategies in comprehension of expository text. Scandinavian Journal of Psychology, 46(2), 107-117.

Smagorinsky, P. (2001). If meaning is constructed what's it made from? Toward a cultural theory of reading. Review of Educational Research, 71(1), 133-169.

Snyder, B., \& Pressley, M. (1995). Introduction to cognitive strategy instruction. In M. Pressley \& V. Woloshyn (Eds.), Cognitive strategy instruction that really improves children's academic performance (pp. 1-18). Cambridge, MA: Brookline.

Spring, C., \& Prager, J. (1992). Teaching community-college students to follow the train of thought in expository texts. Reading and Writing: An Interdisciplinary Journal, 4(1), 33-54.

Stanovich, K. E. (1986). Matthew effects in reading: Some consequences of individual differences in the acquisition of literacy. Reading Research Quarterly, 21(4), 360-407.

Stevens, R. J., Slavin, R. E., \& Farnish, A. M. (1991). The effects of cooperative learning and direct instruction in reading comprehension strategies on main idea identification. Journal of Educational Psychology, 83(1), 8-16.

Taraban, R., Rynearson, K., \& Kerr, M. (2000). College students' academic performance and self-reports of comprehension strategy use. Reading Psychology, 21(4), 283-308.

Tekin-İftar, E., \& Kırcaali-İftar, G. (2015). Özel eğitimde yanlışsız öğretim yöntemleri [Errorless teaching methods in special education]. Ankara: Nobel Yayın Dağıtım.

Temur, T. (2003). Okunabilirlik (readability) kavramı [Concept of readability]. Türklük Bilimi Araştırmaları Türkçenin Öğretimi Özel Sayısı, 13(13), 169-180.

Tomitch, L. M. (2000). Teaching main ideas. Are we really teaching? Linguagem \& Ensino, 3(1), 45-53.

Tompkins, G. E. (2006). Literacy for the $21^{\text {st }}$ century: A balanced approach (4th ed.). Upper Saddle River, NJ: Pearson.

Torgeson, J. K. (1982). The learning disabled child as an inactive learner. Topics in Learning and Language Disabilities, 2(1), 45-52.

Türk Dil Kurumu. (2005). Türkçe sözlük [Turkish dictionary] (10. baskı). Ankara: Türk Dil Kurumu Yayınları. 
Vacca, R. T., \& Vacca, J. L. (2007). Content-area reading: Literacy and learning across the curriculum. Boston, MA: Allyn and Bacon.

van den Broek, P., Lynch, J. S., Naslund, J., Ievers-Landis, C. E., \& Verduin, K. (2003). The development of comprehension of main ideas in narratives: Evidence from the selection of titles. Journal of Educational Psychology, 95(4), 707-718.

Warren, L., \& Fitzgerald, J. (1997). Helping parents to read expository literature to their children: Promoting mainidea and detail understanding. Reading Research and Instruction, 3(4), 341-360.

Watson, S. M. R., Gable, R. A., Gear, S. B., \& Hughes, K. C. (2012). Evidence-based strategies for improving the reading comprehension of secondary students: Implications for students with learning disabilities. Learning Disabilities Research \& Practice, 27(2), 79-89.

Williams, J. P. (1986). Teaching children to identify the main idea of expository texts. Exceptional Children, 53(2), 163-168.

Williams, J. P. (1988). Identifying main ideas: A basic aspect of reading comprehension. Topics in Language Disorders, 8(3), 1-13.

Williams, J. P. (2004). Teaching text structure to improve reading comprehension. In H. L. Swanson, K. R. Harris \& S. Graham (Eds.), Handbook of learning disabilities (pp. 293-305). New York: Guilford Press.

Williams, J. P. (2005). Instruction in reading comprehension for primary-grade students: A focus on text structure. Journal of Special Education, 39(1), 6-18.

Williams, J. P., Brown, L. G., Silverstein, A. K., \& de Cani, J. S. (1994). An instructional program in comprehension of narrative themes for adolescents with learning disabilities. Learning Disability Quarterly, 17(3), 205-221.

Winograd, P., \& Johnson, P. (1982). Comprehension monitoring and the error detection paradigm. Journal of Reading Behavior, 14(1), 61-76.

Wolf, M. M. (1978). Social validity: The case for subjective measurement or how applied behavior analysis is finding its heart. Journal of Applied Behavior Analysis, 11(2), 203-214.

Yüksel, A. (2010). Okuma güçlüğü çeken bir öğrencinin okuma becerisinin geliştirilmesine yönelik bir çalışma [A study about improving one's reading skills who has reading disability]. Kuramsal Ĕgitimbilim Dergisi, 3(1), 124-134. 


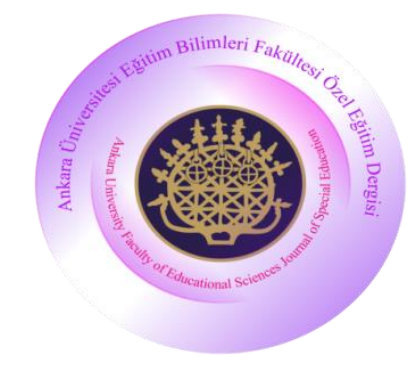

RESEARCH

\title{
Ankara University Faculty of Educational Sciences Journal of Special Education
}

\author{
Year: 2018, Volume: 19, Number: 2, Page No: 303-334
}

DOI: 10.21565/ozelegitimdergisi.315887

\section{The Instructionon Identifying Main Ideas in Improving the Reading Comprehension of Poor Readers}

\author{
IIlhan ILTER \\ Kahramanmaras Sutcu Imam University
}

\begin{abstract}
In this study, the effect of the main ideas strategy instruction on the development of the reading comprehension of three fourth-grade students who had difficulty in reading, was assessed by using a multiple-probe design across the participants. The data were analyzed by means of graphical analysis. The participants' reading comprehension performance in the teaching sessions and in full probes was evaluated through the use of short-answer reading comprehension questions that consisted narrative texts. The maintenance of the ability to identify the main ideas was probed at three and five weeks following the implementation of the main ideas instruction. In addition, social validity data were used to evaluate the qualitative dimensions of the effects of the instructional program. Findings of this study showed that the instruction on identifying main ideas contributed to all three participants in learning to identify the main ideas and key details, and in maintaining these learned skills and providing a higher-level of reading comprehension performance compared to the baseline probe sessions. All results indicate that the main ideas strategy instruction utilizing the direct instruction model can improve the reading comprehension scores of the participants, identified as poor readers.
\end{abstract}

Keywords: Reading comprehension, main ideas, main idea skill, direct instruction model, good and poor readers.

\section{Recommended Citation}

İlter, İ. (2018). The instruction on identifying main ideas in improving the reading comprehension of poor readers. Ankara University Faculty of Educational Sciences Journal of Special Education, 19(2), 303-334. doi: 10.21565/ozelegitimdergisi.315887

*Corresponding Author: Dr., E-mail: iilter@ ksu.edu.tr, https://orcid.org/0000-0002-4411-200X 
Reading comprehension is a skill that provides people with different perspectives and allows them to make sense of life. It is crucial to be able to identify the main ideas of a paragraph, to distinguish supporting ideas, to explore the relationships between the information, and to synthesize key ideas in textual materials. Such skills are widely accepted academic goals within cognitive reading instruction (Jitendra and Gajria, 2011; Kusdemir and Gunes, 2014). Reading comprehension includes complex cognitive processes that should be used in conjunction with reading to provide the reader with the means to infer new meanings from texts (Smagorinski, 2001). Effective reading comprehension skills include analyzing the structure of the text, identifying the main ideas and details, monitoring comprehension, and summarizing the text (Taraban, Rynearson and Kerr, 2000). However, researchers of reading skills have noted that the foundation of reading comprehension skills is the ability to identify the main ideas in texts (the most important ideas). According to these researchers, this skill should be the main aim of reading instruction for improving comprehension, because the identification of the main ideas is at the centre of any reading programme or reading comprehension instruction (Aulls, 1986; van den Broek, Lynch, Naslund, Ievers-Landis and Verduin, 2003). Knowing how to identify the main ideas and details, and how to proceed to obtain the main points of the text will support readers when they need to summarize the text, explain events and key ideas, identify the topic of a paragraph, and integrate information from throughout the text (Kathleen, 2015).

Aktas and Gunduz (2001) defined the main idea as the primary aim of the writer, or what the writer is trying to say about the topic. They stated that the main idea is expressed in a concrete form, so that the description in the text can constitute a judgement and an important thought. The ability to identify the main ideas or the main points in the text is one of the most important skills in reading. It enables the reader to understand what is being read and is often considered to be a prerequisite for higher-level strategies, such as paraphrasing and summarization (Oxford, 1990; Williams, 1988). Kathleen (2015) notes that the ability to identify the main ideas is a higher-level skill that students develop in elementary grades as a foundation for the acquisition of other critical skills in later grades. In many reading situations, readers are asked to identify the text's main points. This is commonly used to assess the readers' capacity to obtain essential information from the text (Kathleen, 2015; Tomitch, 2000). The comprehension of the main ideas is the basis for readers to make logical inferences from the text as part of their performance of comprehension, and to critically analyze and evaluate their textual knowledge in depth and generate new ideas. In this respect, teaching students how to identify the main ideas and key details that support the main ideas helps them to distinguish the most important information in a text and draw conclusions from what they read (Watson, Gable, Gear and Hughes, 2012).

It is not a simple task to identify the main ideas of a text; they are not immediately apparent (Chang and $\mathrm{Ku}, 2014$; Hennings, 1991). Readers are expected to activate prior knowledge, to make connections between elements of the text, to discover the original thoughts that the writer suggests, and to draw further conclusions beyond the explicit details and main points (cited by Karatay, 2014). The process of identifying the main idea in a text is related to the ability to activate prior knowledge, self-monitoring, self-questioning, reading comprehension, and organizing text information (Garner, 1990; Jitendra, Cole, Hoppes and Wilson, 1998). Research has shown that when teaching the skills of main idea identification to students struggling with reading they used effective paraphrasing skills and were able to recall more main ideas and details (Hagaman and Reid, 2008; Ilter, 2017a; Lauterbach and Bender, 1995). At this point, teaching students about a range of reading comprehension strategies will not only enhance their reading comprehension, but will also develop their awareness of how these improve their reading skills (Beck, Buehl and Barber, 2015). The ability to infer meanings from the text is probably one of the most crucial skills for the overall achievement of our schools (Gunes, 2000; Williams, 1988). Previous research has shown that teaching reading skills has contributed significantly to students' ability to understand what they read (Jitendra, Hoppes and Xin, 2000; Klingner, Vaughn and Schumm, 1998; Malone and Mastropieri, 1992; Stevens, Slavin and Farnish, 1991; Williams, Brown, Silverstein and deCani, 1994). All of these results show that teaching about reading strategies can promote the development of the reading abilities of students (Graves, 1986).

The aim of this study was to examine the effects of instruction about identifying main ideas on the reading comprehension performance of fourth-grade students who had difficulties with reading comprehension. In this 
study, the main idea identification skill was chosen as the focal point in the teaching of reading comprehension strategies. The comprehension of main ideas has strong pedagogical implications for reading instruction and, hence, teaching students the ability to locate main ideas, details, and themes from a text is a worthwhile investment of instructional time with long-term benefits (Kathleen, 2015). Therefore, teaching main idea skills enables students to become more independent, proficient, and critical readers (Tomitch, 2000). The study was designed to examine whether the main idea skills paired with strategy instruction utilizing the direct instruction model had an effect on the development of students' reading comprehension, and to observe whether the skills learned were maintained. The literature review revealed that experimental type research related to main ideas and details skills in reading comprehension in Turkey was limited (e.g., Kusdemir and Gunes, 2014; Pilten, 2007). Accordingly, it was thought that this study would make an important contribution to the literature and future research, as well as assist teachers who wished to improve the performance of their students who were struggling with reading comprehension in general education classrooms. Within the scope of this purpose, the following research questions were answered.

- Was the main idea strategy, paired with strategy instruction utilizing the direct instruction model, effective in enhancing the reading comprehension of poor readers, and ensuring that the acquired skills were maintained after the intervention?

- What were the views of the students participating in the current study about the main idea skill instruction program?

\section{Method}

\section{Participants}

The sample comprised three of eighteen students who were studying at a randomly selected branch of a primary school in Bayburt, Turkey who scored less than 50\% in two reading comprehension assessments (the second assessment took place two weeks later, but the text questions were different). Three students were selected by means of a reading comprehension test. These students were found to score below the average scores from the assessments, twice. The students' overall average was $28.97 \%$ in the reading comprehension assessments. The other students in these grades who had scored $50 \%$ or more in the two assessments were excluded from the study. This was because the ability to identify the main ideas was intended to be taught to students who had difficulty in reading comprehension. Before implementing the intervention, the researcher (the author of the study) interviewed the three students' teacher to gather some demographic information related to the students. The teacher was given details of the students' pseudonyms and the assessment scores. The participants' names were disguised with pseudonyms in accordance with the ethical rules.

The first participant was given the name of Kadir as a pseudonym, the second, Ayse, and the third, Erkan. Kadir was a ten-year-old boy. His general average was $28.5 \%$ in the reading comprehension measures. In interviews, the teacher explained that Kadir had difficulty in identifying main ideas and details in texts and developing conclusions from the text. The second participant, Ayse was a girl aged nine years old. Her general average was $33.64 \%$ in the reading comprehension assessments. The teacher shared the fact that Ayse was anxious and frustrated during reading in class, and that she had a negative attitude towards reading practice. This situation led to difficulties in fluent reading and comprehension of text material. The third participant, Erkan, was a boy aged ten years old and his general average was 25.52\%. According to the teacher's opinion, Erkan had limited vocabulary knowledge and ability to infer meaning from the text, which made it difficult for him to understand the texts and to generate new ideas. The teacher also explained that Erkan did not take notes independently during lectures or reading, and he frequently used verbatim copying of the texts. When all the data obtained from the teacher's opinions and the reading comprehension measures were considered as a whole, it was understood that these students were poor readers in terms of their reading comprehension. 


\section{Main Idea Skills Instructional Procedures}

The instructional program for identifying main ideas and details consisted of a series of seven lessons adapted from the teaching methods proposed by Carnine, Silbert and Kame'enui (1997) and developed by Jitendra and Gajria (1998). The lessons were as follows respectively. 1) Describe the main-idea strategy, 2) Single-subject of main-idea study, 3) Multiple-subject of main-idea study, 4) Multiple choice items of main-idea study, 5) Identification of distracter sentences and redundant information, 6) Multiple-choice items of main-idea study in which the options are introduced as when something happened, how something is done, what happened, why and where questions and 7) Main idea and details review. Each lesson was introduced to the students with the use of the 'Direct instruction model.' The main idea identification instructional activities period averaged eighteen days. Each participant continued to participate in regular teaching sessions until they reached a level of ability sufficient to identify the main idea and details of narrative texts for each lesson. These lessons were such as (Jitendra et al., 1998) Description of main idea identification skills, Main idea single subject activity, Main idea multiple subject activity, Main idea multiple-choice items activity, Identification of sentence distracters activity, Identification of the main idea through the detection of multiple choice texts activity, Multiple choice items in which the options were introduced as when something happened, how something is done, and how something looks questions activity, Main idea and details identification review activity. Each lesson varied from one to three days a week. The duration of the sessions planned for the lessons was approximately 20-30 minutes. Each lesson in the main idea instruction program was extended according to the knowledge and skills learned in the previous lesson. The lessons were arranged to develop a variety of reading comprehension skills (e.g., identifying main ideas and details, categorizing text elements, and paraphrasing the main ideas and relevant details using complete, original sentences). The main idea skills instructional procedures consisted of the researcher's instructions, presenting expressions about the comprehension of main ideas, identification of the rules, narrative texts, individual corrective feedback to students concerning their effective use of the strategy, and main idea skills activities. Experimental implementation was carried out by the researcher.

\section{Data Collection Tools}

Reading comprehension tool. A reading comprehension text was initially used to measure the participants' reading comprehension skills to determine whether they were poor readers. The researcher examined various sources at participants' reading level and selected a narrative text consisting of 550 words and four paragraphs. Then, he developed twelve short-answer comprehension questions involving both recall and overall understanding questions. The researcher directly transcribed the answers given by the participants, including both the questions and their correct answers. The participants' level of reading comprehension was determined according to the correct answers given. In the evaluation of the two types of questions of the text, three points were given to students if they answered the questions fully and correctly. Two points were given to students if they answered the questions more than half correctly and one point to those who answered less than half correctly. No points were given to those who did not answer the questions fully and correctly. The sum of the points taken to calculate the percentage was divided by the sum of the points to be taken and the level of reading comprehension (Akyol, 2010; Yuksel, 2010). A copy of the data obtained from the participants was delivered to two independent raters in the field of literacy education. The agreement rate between raters was determined by the formula Agreements /Agreements + Disagreements x 100. The inter-rater reliability coefficient was found to vary between .84 and .90 .

Social validity. The participants were interviewed at the end of the intervention in order to assess the social validity of the main idea identification instructional program. The participants were individually asked to evaluate the effectiveness of the strategy training individually and to share what they liked most about the teaching activities during the teaching sessions.

Short-answer questions. The short-answer questions were used to assess the effect of the ability to identify the main ideas instruction on the development of participants' reading comprehension in the baseline, full 
probe, and maintenance probe sessions. The short-answer questions were developed using different narrative texts. Ten short-answer questions were produced in each probe session to monitor whether participants' improvement in their reading comprehension skills integrated the performance of main idea identification. There were five questions on the level of recall about the information in the narrative texts, and five overall understanding questions that required students to make inferences from the text and to determine the main ideas and details. The participants were asked to give written answers to these questions. In the evaluation of both the recall and overall understanding questions, one point was given to the students if they answered the recall questions fully and correctly, 0.5 points was given the students if they give the correct answers partially, but no points were awarded if they did not give the correct answers at all. The maximum score a participant could achieve from the short-answer questions was ten, while the minimum score was zero. The number of correct responses was represented by the average of the participants' correct responses to the questions. With these averages, levels of reading comprehension by the participants were determined.

\section{Research Design}

A multiple-probe design across participants was used in this study (Tekin-Iftar and Kircaali-Iftar, 2015). The intervention process consisted of the baseline, full probe sessions, teaching sessions, and maintenance probe sessions.

Baseline. The baseline probe sessions were administered until stable data were obtained from each participant. In these sessions, the opportunity was used to gather data on the participants' initial performance of the skill in order to identify the main ideas to be taught. Therefore, the worksheets containing ten short-answer questions related to the narrative texts were used to evaluate their reading comprehension. The participants were asked to read the texts independently, silently, and to give written responses to the questions. They were given enough time to respond to the short-answer questions, which took approximately 15-20 minutes.

Full probe sessions. The full probe sessions related to the dependent variable (the development of reading comprehension level) of the current study were administered at the end of teaching sessions for each participant. The full probe sessions were administered in the same way as the baseline probes. The participants were given worksheets to determine their level of achievement in reading. The correct responses of the participants to the ten short-answer questions on the worksheets were determined and the correct number of responses was calculated.

Intervention sessions. The main ideas identification instructional lessons were administered using the direct instruction method. Firstly, the level of baseline probes data related to the participants' reading comprehension skill integrated with the main ideas identification performance were collected. Each teaching session was administered in Turkish language lessons for each participant per day. The teaching sessions continued until each participant achieved the target criterion and achieved stable data in the ability to identify the main ideas. The target criterion was that the participants were able to identify the main ideas and supporting details of the texts in the paragraphs.

Maintenance. Three and five weeks after the completion of the interventions, maintenance probe sessions were administered in order to assess the accuracy of the participants' gains as a result of the main idea skills training, and to assess the level of maintenance of their ability to identify the main ideas. The maintenance probes were administered in the same way as the baseline probes and full probes were administered. During the maintenance probe sessions, the participants were given no reminder about the skill of main ideas identification, the components, and the teaching program. In these sessions, only worksheets containing ten short-answer questions were presented to the participants, as in the full probe sessions.

\section{Procedural Fidelity and Reliability of the Study}

Reliability analyses were conducted by two independent observers to ensure inter-observer reliability and procedural fidelity in this study. The first observer was a research assistant who has a $\mathrm{PhD}$ in education. The other was the participants' school teacher. The teacher has a bachelor's degree in primary school education and 12 years 
of teaching experience. The teacher had worked for five years in the school where the study was conducted. The observers participated in the probes and teaching sessions. They were informed about the main idea identification instructional program by the investigator. Two types of data were gathered: reliability between the raters and the procedural fidelity. The first was the inter-coder reliability. Inter-coder reliability was a comparison of assessments of what two observers were doing independently of each other, but at the same time achieving the target behavior. In order to gather inter-observer reliability data, data were collected and analyzed in $30 \%$ of the full probe sessions and the teaching sessions. The reliability between the observers was calculated using the formula Agreements/Agreements + Disagreements x 100 (Tekin-Iftar and Kircaali-Iftar, 2015). The inter-observer reliability was found to be $88 \%$ in the full probe sessions and $92 \%$ in the teaching sessions.

Another assessment of the study's reliability was procedural fidelity. This step determined the extent to which the teaching practices carried out by the implementer conformed to the pre-prepared intervention plan. For this purpose, the implementer's expected behaviors in the intervention plan were determined and aprocedural fidelity form was prepared. One or more observers marked the procedural fidelity form as to whether the teaching practice included or did not include the implementer's behaviors (Tekin-Iftar \& Kircaali-Iftar, 2015). For the assessment of the procedural fidelity of the intervention, a checklist of implementers' behaviors was prepared for this study. These behaviors included the stages of a series of the direct instruction model (Ellis, Deshler, Lenz, Schumaker and Clark, 1991) as follows: a) Describe the method, b) Model the method (Physical and oral modeling of the method), c) Verbally elaborate and rehearse (verbal rehearsing), d) Practice acquisition (practice or practice acquisition of the method), e) Undertake advanced practices, and f) Assessing method. The observers independently followed $30 \%$ of the teaching sessions and marked the items in the procedural fidelity data checklist given to them. In the procedural fidelity analysis, the formula developed by Billingsley, White and Munson (1980) was used [(Observed implementer's behavior / Planned implementer's behavior) x100]. Inter-rater agreement was found to be $89 \%$.

\section{Results and Discussion}

In this study, in the baseline, the mean number of correct answers to the short-answer questions for Kadir, Ayse, and Erkan was 2.66, 2.25, and 1.2, respectively. The mean number of correct answers during the full probe sessions for Kadir, Ayse, and Erkan was 8.25, 8.0, and 8.25, respectively. The maintenance performance for Kadir, Ayse, and Erkan was 8.5, 8.25, and 8.5, respectively. For all participants, the treatment effects were maintained across three and five weeks following the implementation of the intervention. All participants maintained the main idea identification skills they had acquired by the end of the intervention. Hence, they met the target criteria. All participants increased the number of correct responses to the short-answer questions. The results suggested that the main idea instructional program could effectively increase students' comprehension of narrative texts. The results of this study indicated that the main ideas identification strategy paired with strategy instruction utilizing the direct instruction model could improve the reading comprehension scores of poor readers. Furthermore, the social validity results showed that main idea instruction was found to be effective in improving the participants' understanding of narrative texts and comprehending main ideas and details. It was found that the views of the participants were generally positive, that they had monitored improvement in their reading comprehension with the achievement of this skill, and they shared that they identified supporting ideas and important details, and descriptive text elements in texts. The findings of this study confirmed that that the main ideas strategy instruction had a high degree of success in improving students' reading and understanding of texts, and processing information necessary to identify the main ideas and details in texts. This finding supported the view that this strategy of teaching reading helps learners to process knowledge more effectively and guides their comprehension performance (Katims and Harris, 1997). Previous research hasshown that main idea skills instruction had significant improvements on students' reading comprehension (Bakken, Mastropieri and Scruggs, 1997; Jitendra et al., 2000; Kusdemir and Gunes, 2014; Malone and Mastropieri, 1992; Stevens et al., 1991). In Pilten's (2007) study, it was found that the experimental group, which was trained on how to identify main ideas, recalled more main ideas and details in texts than the control group of students who were taught with traditional reading 
instruction. Other research on reading comprehension strategies confirmed the practical utility of strategy teaching in developing comprehension of the main ideas and details and in the development of reading comprehension skills (Ellis and Graves, 1990; Hagaman, Casey and Reid, 2016; Hagaman and Reid, 2008; Ilter, 2017a; Lauterbach and Bender, 1995). According to these results, it can be considered that the direct instruction of the reading strategies is mediated by the poor readers.

\section{Limitations and Implications}

The results of the research showed that teaching the main idea skill contributed to all participants' learning the skill of identifying main ideas. As in all research, this study had limitations that could be addressed in future research. First, the number of participants in the study was limited to three fourth-grade students. The research findings would need to be replicated with different participants at different grade levels in order to be able to generalize the findings. Secondly, it was aimed at students who were determined to be at a poor reading level in terms of their understanding of what they read, taking into account the results of the reading comprehension assessment text developed by the researcher in the selection of the study sample. Future research should include reading measures involving the assessment of both students' word recognition and reading comprehension skills. Thirdly, the main ideas identification skill was administered with individual instruction to each participant. In future studies, it could be determined whether the main idea instruction program is equally effective in small groups or whole class environments. Fourthly, narrative texts were used in all probes and teaching sessions to determine the effect of the strategy instruction on the development of participants' reading comprehension. The reason for the use of narrative texts was to teach them to identify events, people, and time and space elements and reach solution points in order to comprehend the main idea of such texts. The texts were selected to help them to both understand and have fun in reading, in terms of enabling the students to draw a story map. However, reading skills researchers have noted that more 'important emphasis should be placed on comprehending the expository texts' (Karatay, 2014; Williams, 1986), because reading expository texts, for poor readers, is much more difficult and complex than reading narrative texts. Moreover, the problems of identifying the main ideas will be more prominent when expository texts are taken into consideration (Williams, 2005). Future research should address teaching students to identify the main idea of expository texts. Fifthly, generalization was not examined. The research did not consider whether any of the participants would generalize performance of main ideas and details identification skills to new or different types of contexts or texts. Future studies should include generalization probe sessions to establish whether participants are able to generalize the main idea skills to different texts or scientific texts, because it is important to monitor how poor readers can effectively follow how they use or generalize the strategies they have learned (Graves, 1986). Lastly, another limitation of this research was that social validity data were collected from only the participants of this study. It may be advisable to collect social validity data from different people, such as teachers and implementers related to the instructional activities to be conducted, in future research. All findings should be replicated in future research for different student populations and learning environments and should be expanded with different reading variables.

\section{Conclusions}

The results established that the main idea instruction improved the students' reading comprehension skills. The findings showed that strategy teaching contributed to the identification of main ideas and details supporting the main idea in narrative texts. All three participants maintained the permanence of the learned skills and demonstrated a higher level of comprehension performance compared to the baseline. The participants showed significant improvements in their understanding of reading skills, using the main idea identification skills learned from the baseline probe sessions to the full probe sessions at the end of the intervention implemented. As in previous research, the results of this study were promising in that students who had difficulties in comprehension were able to acquire the ability to determine the main ideas. The findings highlighted the importance of structured instruction in helping students to generate main ideas and details, and so develop their reading comprehension skills. In teaching sessions, it is simple and practical for teachers to use main idea instruction to improve their students' reading comprehension performance. Structured main idea instruction has strong pedagogical 
implications to help learners to develop effective reading comprehension strategies. Accordingly, main idea skills training can be called a roadmap for the reading and reading comprehension process for students struggling with reading comprehension in general education classes (Pressley and McCormick, 1995). However, teachers of specific content areas, such as social studies or science, working with students who have problems with reading comprehension, can prevent and remediate these students' reading difficulties and improve their understanding of what they read through direct instruction in the ability to identify main ideas. It is well known that many students have problems understanding textual materials in content area classrooms (Carriedo and Tapia, 1996; Massey and Heafner, 2004). Teachers can help their students to identify or generate main ideas, eliminate unnecessary information, remember what they read, and become aware of the reading strategy to use, by teaching a series of specific strategies. This can also serve as a way for students to become more independent, competent and more critical readers in the future. 